\author{
Beata Giesen \\ Uniwersytet Łódzki, Polska \\ e-mail: bgiesen@wpia.uni.lodz.pl \\ ORCID: 0000-0003-3962-9482 \\ Krzysztof Kurosz \\ Uniwersytet Łódzki, Polska \\ e-mail: kkurosz@wpia.uni.lodz.pl \\ ORCID: 0000-0003-0605-3392
}

\title{
MASKA ARTYSTYCZNA - POMIĘDZY DOBREM OSOBISTYM, ARTYSTYCZNYM WYKONANIEM A UTWOREM
}

\author{
ARTISTIC MASK: BETWEEN PERSONAL RIGHT, \\ ARTISTIC PERFORMANCE AND A WORK
}

\begin{abstract}
The artistic mask, understood as a "factitious", creatively developed identity of a person, escapes the long-accepted, and already well-established in the private law, classifications of legal interests. This makes it difficult to answer the fundamental question of whether, and if yes, then subject to what conditions, the artistic mask is protected, and also to establish the legal framework for contractual disposal thereof. This problem becomes particularly important these days, as discussions across a variety of platforms are being held on the development of one's own personality, self-creation, how we present ourselves to others, and how far we can control how others present us. Moreover, the structure of the mask draws our attention to the area where the material,
\end{abstract}


or tangible, and the immaterial, intangible, interpenetrate each other, the area that is characterized by the conflict of interest, whether or not it pertains to property-related, or economic, interest.

The academic research undertaken so far allows to conclude that there are many faces of the artistic mask. Therefore, a question arises whether it is possible at all to assign it to one of the categories of protected interest that is already recognized by the law, namely an image, a work or artistic performance, or it is a new type of legal interest. In our opinion, the problem of the artistic mask is not an anachronistic one, or an artefact from the times of a pursuit to find the grounds for protection of the artists-performers.

The analysis of those who practice as performers allows us to observe that the structure of the mask combines two elements, i.e. the identity and the medium. It is a characteristic feature of the mask that everything that makes up the identity, namely the character, the appearance of an impersonated character, is not real, as it would be in the case of an image of a human being, but is artificially created. Unlike is usually the case with a copyrighted work, it is not a physical object that is the carrier, or the medium, for the mask, but a human being. It can be stated that in the case of the mask, the human being is the original copy of the "work". However, the concept of holding copyright to one's own person is excluded as such.

\section{KEYWORDS}

artistic mask, artificial identity, digital personality, artistic image

\section{SLOWA KLUCZOWE}

maska artystyczna, sztuczna tożsamość, osobowość cyfrowa, wizerunek artystyczny

\section{WPROWADZENIE}

„Maska pozwala człowiekowi, który ją nosi, chwilowo, póki działa czar, stać się istotą, którą przedstawia. Na czas trwania gry (skoro mamy do czynienia z maską, ewidentnie jest to gra) bezimienny Etrusk staje się Phersu"1. Tymi słowami J. Stagl, badając pojęcie osoby w ujęciu jurydycznym z perspektywy historycznej, oddaje istotę maski. Znaczenie badań podjętych przez powołanego autora dalece wykracza poza ustalenie li tylko ,potencjału antropologicznego”

${ }^{1}$ J. F. Stagl, Persona: maska z ludzka twarzq. O archeologii prawnej prawa osobowego, „Studia Iuridica” 2021, t. LXXXVI, s. 256 i n. 
maski w procesie kształtowania się prawnego pojęcia osoby². Okazuje się bowiem, że są one również przydatne do wyjaśnienia prawnej koncepcji maski. W polskiej nauce temu zagadnieniu poświęcono już wiele uwagi. Pomimo to, do dzisiaj w tej kwestii nie została postawiona przysłowiowa kropka nad ,i”.

Nic nie oddaje lepiej istoty współczesnego pojęcia maski artystycznej aniżeli zwyczaj posługiwania się nią przez aktorów występujących na scenach starożytnej Grecji, a potem w XVI-wiecznej komedii dell'arte, czy francuskiego teatru molierowskiego. Maska skrywała naturalne oblicze artysty, czyniła jego osobowość niewidoczną, pozwalając mu w ten sposób wcielić się w kogoś innego. Posłużenie się nią umożliwiało pokazanie cech charakteru, emocji, uczuć, ale i statusu społecznego prezentowanej postaci. Maska była zatem rekwizytem w procesie kreacji twórczej, służyła do „stworzenia” tożsamości przedstawianej postaci scenicznej. Zdarzało się, że odgrywana systematycznie postać utrwalała się $\mathrm{w}$ zbiorowej pamięci, wykraczając niejednokrotnie poza ramy roli, dla której została stworzona. W ten sposób pojęcie „maska artystyczna” stało się synonimem wykreowanej, fikcyjnej postaci, której bliskość z realnym światem sprawiała, że przedstawiana przy jej pomocy osoba na swój sposób „ożywała”. Posiadała bowiem cechy właściwe każdemu człowiekowi, takie jak np. wygląd zewnętrzny, charakterystyczny sposób mówienia, gestykulowania, poruszania się, sobie właściwy styl ubierania czy też makijażu.

Maska artystyczna od początku wzbudzała zainteresowanie przede wszystkim teatrologów, ale nie tylko $\mathrm{ko}^{3}$. Od dawna jest ona obiektem uwagi również prawników, a to dlatego, że wiele kwestii z nią związanych wymaga jeszcze wyjaśnienia. Maska artystyczna wymyka się bowiem przyjętym i utrwalonym w obszarze prawa prywatnego klasyfikacjom, co utrudnia zarówno udzielenie odpowiedzi na zasadnicze pytanie, czy, a jeśli tak, to pod jakimi warunkami podlega ona ochronie, jak i ustalenie ram prawnych dla umownego dysponowania ,wykreowaną tożsamością", skoro już w praktyce tzw. merchandising image stał się niemalże codziennością ${ }^{4}$. Zainteresowanie prawników maską artystyczną wiąże się też zapewne z pojawieniem się nieznanych dotąd możliwości wykorzystania fikcyjnych postaci czy sztucznie wykreowanych tożsamości. Nowe techniki, związane przede wszystkim z technologią cyfrową, stwarzają możliwość skanowania wizerunku osoby fizycznej, a następnie wprowadzenia w nim zmian, tak aby pierwowzór nie był już rozpoznawalny, a jednocześnie wzbudzał wrażenie déjà vu.

${ }^{2}$ J. F. Stagl powołuje się w tym względzie na niemieckiego uczonego R. Spaemanna, który zwraca uwagę na ,potencjał antropologiczny” konceptu osoby, R. Spaemann, Was macht Personen zu Personen?, (w:) H. Thomas, J. Hattler (Hrsg.), Personen - Zum Miteinander einmaliger Freiheitswesen, Frankfurt am Main 2012, s. 29-44.

${ }^{3}$ E. G. Craig, The Actor and The Über-Marionette, "A Monthly Journal of the Art of the Theatre" 1909, No 2, s. 9, w nowszej literaturze: S. Schneider, Über die Maske des Schauspielers in den theatertheoretischen Schriften Wsewolod Meyerholds und Bertolt Brechts, München 2009.

${ }^{4}$ A. Glanc-Walkiewicz, B. Gadek, Image merchandising jako element komercjalizacji dóbr osobistych, „Prawo Mediów Elektronicznych” 2020, z. 1, s. 5. 
Chciałoby by się powiedziecie, że jest to pewien rodzaj twórczego opracowania cudzego wizerunku, a nawet szerzej, adaptacji cudzej osobowości. Choć jest ona przykryta efektami cyfrowymi, to przebłyskuje na zewnątrz'5

W tym stanie rzeczy naturalne staje się pytanie, o pozycję prawną osób, które posłużyły za wzór albo wręcz za swego rodzaju nośnik sztucznie wykreowanej postaci. Artykułowa postać prezentowanego opracowania nie pozwala na poruszenie wszystkich aspektów zasygnalizowanej problematyki. Dlatego skupiamy się na kwestiach zasadniczych, a mianowicie na wskazaniu podstawowych cech maski artystycznej oraz na próbie ustalenie jej natury prawnej.

\section{MASKA ARTYSTYCZNA W ROZWAŻANIACH DOKTRYNY I JUDYKATURY}

Nie sposób dzisiaj dokładnie ustalić, od kiedy pojęcie maski znalazło się w sferze badań prawników. Dość powiedzieć, że już w 1903 r. niemiecki uczony Siegfried Rietschel wiązał to pojęcie z wizerunkiem człowieka, pojmowanym jako cecha identyfikująca daną osobę $e^{6}$. Warto też odnotować, że powołany autor ${ }^{7}$, podobnie jak Josef Kohler ${ }^{8}$, maską artystyczną obejmował również wizerunek aktora odgrywającego rolę. W 1931 r. niemiecki uczony Alexander Elster stawiał pytanie, czy maska artystyczna korzysta z ochrony przed naśladownictwem ${ }^{9}$. Dwadzieścia lat później ten sam uczony w następujących słowach wyjaśniał istotę tego zjawiska: „W przypadku maski, pod którą występuje aktor, trzeba odróżnić, czy pod tą maską ujawnia się w przeważającym stopniu sam aktor osobiście, tak że zasadne jest mówienie o prawie do wizerunku aktora $\mathrm{X}$, także wówczas, gdy odgrywa on króla Lear (...), czy o pewien model maski powiedzmy ukształtowana w sposób twórczy - o »drugą《 twarz. Nie chodzi

${ }^{5}$ Jeden z najbardziej znanych aktorów specjalizujący się w rolach fikcyjnych postaci, długo nie był kojarzony z wyglądu swej twarzy. Chodzi o Andy Serkisa - odtwórcy Goluma, oraz szympansa Cezara z „Planety Małp”. W opracowaniu na temat charakterystyki jego gry aktorskiej wskazano, że maska cyfrowa ,przysłaniając (niekiedy zupełnie) jego prawdziwe oblicze, równocześnie uwidacznia na ekranie najdrobniejsze niuanse występu" - K. Kalbarczyk, A. Serkis, $C y$ frowy kameleon, http://ekrany.org.pl/kino_wspolczesne/andy-serkis-cyfrowy-kameleon/ (dostęp: 26.05.2021 r.).

${ }^{6}$ S. Rietschel, Das Recht am eigenen Bilde, „Archiv für die civilistische Praxis” 1903, z. 1-2, s. 167.

${ }^{7}$ Ibidem, s. 193.

${ }^{8}$ J. Kohler, Das Eigenbild im Recht, Berlin 1903, s. 20.

${ }^{9}$ A. Elster, Genießt die Maske Schutz gegen Wiedergabe der Nachahmung?, „Der neue Weg" 1931, nr 2, s. 1. 
przy tym o mimiczne elementy gry aktorskiej, lecz o artystycznie ukształtowany obraz ${ }^{10 "}$.

W prawie polskim prawne znaczenie wyodrębnienia konceptu maski artystycznej dostrzegał Stefan Ritterman. Jeszcze na gruncie ustawy o prawie autorskim z 1926 r. ${ }^{11}$ przez to pojęcie rozumiał on ,,...) wizerunek, jaki artysta sztucznie sobie stwarza dla oddania cudzej, a nie własnej postaci”'12. Autor ten odróżnia przy tym tak rozumianą maskę artystyczną od rzeczywistego wizerunku aktora. W ujęciu S. Rittermana maska artystyczna nie stanowi elementu wizerunku aktora, lecz dzieła, które podlega ochronie autorsko-prawnej. Trzeba jednak odnotować, że stanowisko powołanego autora służyło rozciągnięciu ochrony prawno-autorskiej na świadczenia aktorów, które wówczas nie były objęte kategorią prawa pokrewnego ${ }^{13}$. Na pierwszy rzut oka mogłoby się wydawać, że dla S. Rittermana zasadniczą kwestią, uzasadniającą akcentowanie różnicy pomiędzy tymi dwoma dobrami, była potrzeba ustalenia, czy aktorowi przysługuje ochrona jego kreacji (maski artystycznej), pomimo braku przepisów wprost obejmujących ochroną artystyczne wykonania ${ }^{14}$. Uważna lektura jego wypowiedzi unaocznia, że autor ten dostrzegał potrzebę ochronny maski artystycznej w szerszym kontekście aniżeli tylko ten, wyznaczony potrzebą ochrony artystycznego wykonania. Świadczą o tym następujące słowa komentarza: „Jest jednak rzeczą zastanowienia godną, czy z uwagi na znaczną uchwytność maski artystycznej w szerokim tego słowa znaczeniu, obejmującym również typy wizualne, stworzone przez znakomitych artystów (Solski, Kamiński, Charlie Chaplin, Jannigs), z uwagi zarazem na wybitny stopień pierwotnej, a nie tylko odtwórczej twórczości, jaka właśnie w dziedzinie wizualnej artyzmu może się ujawnić (śmiesznym byłoby np. twierdzić, że Charlie Chaplin li tylko »odtwarza« postać, stworzoną przez autora scenariusza), nie należałoby w tej dziedzinie dać artyście szerszej, jeśli nie pełnej ochrony prawno-autorskiej”"15.

Również w polskim orzecznictwie dość szybko ujawnia się konieczność uznania maski artystycznej jako autonomicznego, podlegającego ochronie dobra prawnego. Wystarczy w tym miejscu przywołać rozstrzygnięcia Sądu Najwyższego, w znanej i często przywoływanej w literaturze przedmiotu sprawie

${ }^{10}$ R. Voigtländer, A. Elster, H. Klein, Die Gesetze, betreffend das Urheberecht an Werken der Literatur und der Tonkunst sowie an Werken der Bilden Kunst und der Photographie, Berlin 1952, s. 26.

${ }^{11}$ Ustawa z dnia 29 marca 1926 r. o prawie autorskim (tekst jedn. Dz.U. z 1935 r., nr 36, poz. 260).

${ }^{12}$ S. Ritterman, Komentarz do ustawy o prawie autorskim, Kraków 1937, s. 120.

${ }^{13}$ Ibidem.

${ }^{14}$ T. Grzeszak, Prawo do wizerunku i prawo adresata korespondencji, (w:) J. Barta (red.), System Prawa Prywatnego. Tom 13. Prawo autorskie, Warszawa 2017, s. 793. Podobnie M. Cyran z powołaniem na T. Grzeszak, Natura prawna maski artystycznej, „Palestra” 2010, nr 11-12, s. 123.

${ }^{15}$ S. Ritterman, Komentarz..., uwaga w przypisie nr 3, s. 120. 
publikacji pocztówek przedstawiających Grażynę Staniszewską w roli Danuśki w filmie „Krzyżacy”16. Przypomnijmy, na gruncie ustawy z dnia 10 lipca 1952 r. o prawie autorskim ${ }^{17}$, w dwóch orzeczeniach dotyczących tego samego stanu faktycznego, Sąd Najwyższy uznał prawo producenta do wykorzystania maski artystycznej, stworzonej przez aktora do celów reklamowych, pod warunkiem że reklama służy bezpośrednio propagowaniu filmu ${ }^{18}$. Wprawdzie $\mathrm{w}$ uzasadnieniu powołanych rozstrzygnięć pojawia się pojęcie maski artystycznej ujmowanym jako dobro odrębne od wizerunku aktora, to jednak Sąd Najwyższy nie wyjaśnia ani jego natury, ani nie wytycza bliżej konturu tego pojęcia, ograniczając się wyłącznie do udzielenie odpowiedzi na pytanie, dlaczego dopuszczalna jest komercyjna eksploatacja wizerunku, choć jest on dobrem osobistym, bez dodatkowej zgody aktora (pod warunkiem że utrwalony wizerunek jest częścią utworu filmowego). Warto odnotować, że takie podejście spotkało się z krytyczną oceną Andrzeja Kopffa, który słusznie zarzucił sądowi, że nie odgranicza w sposób należyty osobistego wizerunku aktora odgrywającego rolę od sytuacji, w której ów aktor ,przywdziewa maskę”, co prowadzi do ukrycia jego osobistych, wizualnych $\operatorname{cech}^{19}$. Dla A. Kopffa, jak się wydaje, maska artystyczna była pojęciem związanym wyłącznie z artystycznym wykonaniem utworu.

Po wejściu w życie ustawy z dnia 4 lutego 1994 r. o prawie autorskim i prawach pokrewnych ${ }^{20}$, zawierającej odrębną regulację dotyczącą artystów wykonawców, w literaturze zostało wyrażone zapatrywanie o częściowej dezaktualizacji koncepcji o ochronie maski artystycznej ${ }^{21}$. Na skutek ustawowego uregulowania praw artystów wykonawców zaniechano prób konstruowania odrębnego od wizerunku przedmiotu ochrony. Charakterystyczna jest w tym względzie wypowiedź Teresy Grzeszak, która zauważa, że wizerunek „ustalony w przekazie telewizyjnym

${ }^{16}$ Wyrok Sądu Najwyższego z dnia 15 kwietnia 1965 r., I CR 58/65, OSPiKA 1966, nr 6, poz. 130, z glosą A. Kopffa, zob. także glosę do niniejszego orzeczenia autorstwa B. Michalskiego, „Państwo i Prawo” 1967, z. 4-5, s. 801, a także wyrok Sądu Najwyższego z dnia 19 maja 1967 r., I CR 624/66, OSNCP 1968, nr 8-9, poz. 141.

${ }^{17}$ Dz.U. nr 34, poz. 234.

${ }^{18} \mathrm{Na}$ marginesie warto jednak odnotować, że już w wyroku Sądu Apelacyjnego w Warszawie z 8 maja 1992 r., I ACr 215/92, LEX nr 62589, w którym analizowano wpływ zmiany nośnika, na którym jest utrwalony utwór filmowy oraz pól eksploatacji, na sytuację prawną aktorów, nie znajdujemy ani słowa na temat „maski artystycznej”. W uzasadnieniu rozważano, czy doszło do naruszenia dóbr osobistych w postaci wizerunku, ewentualnie „wizji artystycznej”. Sąd uznał, że zmiana nośnika ani nie zniekształciła utworu, ani też nie naruszyła dóbr osobistych powoda, w szczególności prawa do prywatności, pomimo odmiennej niż kinowa formy odbioru (oglądanie w warunkach domowych, możliwość zatrzymywania i wielokrotnego oglądania wybranych scen). Wystarczające dla rozstrzygnięcia sprawy było odwołanie się do konstrukcji zgody na wykorzystanie wizerunku i efektów gry aktorskiej (poprzez wzięcie udziału w produkcji filmowej).

${ }^{19}$ A. Kopff, Glosa do wyroku SN z 15.04.1965 r., I CR 58/65, „Orzecznictwo Sądów Polskich” 1966, z. 6, poz. 130.

${ }^{20}$ Tekst jedn. Dz.U. z 2019 r., poz. 1231, z późn. zm.; dalej: pr.aut.

${ }^{21}$ J. Balcarczyk, Prawo do wizerunku i jego komercjalizacja, Warszawa 2009, s. 39-40. 
spektaklu teatralnego, utrwalony w filmie - staje się integralną częścią artystycznego wykonania"22. W konsekwencji powołana autorka utożsamia pojęcie maski artystycznej z wizerunkiem artysty wykonawcy. Podobnie rzecz ujmuje Andrzej Matlak, kiedy dowodzi, że utrzymanie dodatkowej ochrony wizerunku aktora $\mathrm{w}$ przypadku artystycznego wykonania zachwiałoby pewnością obrotu w przypadku filmów fabularnych. Producent zawsze musiałby się bowiem liczyć z odwołaniem udzielonej przez aktora zgody na rozpowszechnianie jego wizerunku, zaś konstrukcja nadużycia prawa (art. 5 Kodeksu cywilnego ${ }^{23}$ ) jest w tym zakresie niewystarczająca ${ }^{24}$. Odmienne stanowisko zajęli natomiast Janusz Barta i Ryszard Markiewicz. Według powołanych autorów dozwolone wykorzystanie artystycznego wykonania nie przesądza ,automatycznie o dozwolonym wykorzystaniu wizerunku i vice versa"25.

Mylne byłoby jednak przekonanie, że pod rządami nowego prawa autorskiego, które normują prawa pokrewne do artystycznego wykonania, problem maski artystycznej został ostatecznie rozwiązany. Wręcz przeciwnie, wydaje się, że wraz z uchwaleniem prawa autorskiego z 1994 r., naszym zdaniem, zbyt pochopnie, „wtłoczono" maskę artystyczną w ramy artystycznego wykonania, co doprowadziło do osłabienia intensywności badań nad jej istotą. Obecnie uwaga nauki polskiej koncentruje się przede wszystkim na poszukiwaniu kryterium właściwego do nakreślenia linii granicznej pomiędzy prawem do wizerunku aktora, pojmowanym jako zespół cech fizycznych pozwalających na jego identyfikację, a maską artystyczną, przez którą rozumie się wizerunek sceniczny autora, wytworzony przez niego w trakcie odtwarzania roli. Takie podejście jest widoczne u większości przedstawicieli polskiej nauki. Poza wymienionymi już wyżej osobami, w kierunku tym podąża również Justyna Balcarczyk ${ }^{26}$. Podobnie Rafał Kasprzyk, w glosie do sprawy Genowefy Pigwy, wyraźnie stwierdza, że pod pojęciem maski artystycznej kryje się sztuczny wizerunek aktora, stworzony dla oddania kreowanej przez siebie postaci ${ }^{27}$. W tym ujęciu zatem maska artystyczna jest elementem artystycznego wykonawstwa, chronionego prawem pokrewnym. Jednocześnie R. Kasprzyk zauważa, że naśladownictwo maski artystycznej

${ }^{22}$ T. Grzeszak, Prawo do wizerunku i prawo adresata korespondencji, (w:) J. Barta (red.), System..., s. 793, oraz eadem, Reklama a ochrona dóbr osobistych (naruszenie praw osobistych wykorzystanych w reklamie żyjących osób fizycznych), „Przegląd Prawa Handlowego” 2000, nr 2, s. 12.

${ }^{23}$ Ustawa z dnia 23 kwietnia 1964 r. - Kodeks cywilny (tekst jedn. Dz.U. z 2020 r., poz. 1740, z późn. zm.); dalej: k.c.

${ }^{24}$ A. Matlak, Cywilnoprawna ochrona wizerunku, „Kwartalnik Prawa Prywatnego” 2004, nr 2, s. 322-323.

${ }^{25}$ J. Barta, R. Markiewicz, Wokół prawa do wizerunku, „Prace z Wynalazczości i Ochrony Własności Intelektualnej” 2002, z. 80, s. 15.

${ }^{26}$ J. Balcarczyk, Prawo do wizerunku..., s. 35 i n.

${ }^{27}$ R. Kasprzyk, Glosa do wyroku SN z dnia 3 października 2007 r., II CSK 207/07, „Palestra” 2009, z. 9-10, s. 61-72. 
wykracza poza ramy dozwolonego naśladownictwa artystycznej interpretacji, skoro jego istotą jest podszywanie się jednego odtwórcy pod drugiego. W konsekwencji czyn taki godzi w osobowości odtwórcy, czyli w jego prawo do ojcostwa swojej kreacji. Warto odnotować, że R. Kasprzyk kreśli wyraźną linię graniczną pomiędzy naśladownictwem maski artystycznej a naśladownictwem artystycznej interpretacji. $\mathrm{W}$ ocenie tego autora różnica tkwi w tym, że w przypadku naśladownictwa maski artystycznej dochodzi nie tyle do naśladownictwa wykonania, co do przejęcia wykreowanej postaci. R. Kasprzyk nie bez racji pisze o plagiacie maski. Zauważa też, że naśladownictwo maski dotyka „samej osobowości odtwórcy, czyli jego praw do ojcostwa swojej kreacji”"28. Do spostrzeżenia tego, które naszym zdaniem jest niezwykle istotne dla ustalenia natury maski artystycznej, powrócimy jeszcze w toku dalszych rozważań.

Warte odnotowania jest również nieco odmienne podejście Damiana Flisaka, który wydaje się utożsamiać pojęcie maski artystycznej z wizerunkiem artysty. Z lapidarnej wypowiedzi zamieszczonej w komentarzu do art. 81 pr.aut. wynika, że przez pojęcie maski artystycznej rozumie on sztucznie wykreowany wizerunek artysty. Jego ochronę uzależnia jednak od rozpoznawalności osoby kreującej wymyśloną postać. W przeciwnym wypadku - jak przekonuje D. Flisak - w rachubę wchodzi jedynie ochrona kreacji aktorskiej jako artystycznego wykonania ${ }^{29}$.

Z przedstawionych rozważań wynika, że zarówno samo pojęcie maski artystycznej, jak i jej ulokowanie w systemie ochrony prawnej nadal pozostaje źródłem wielu kontrowersji. Zarówno w judykaturze, jak i w doktrynie można zaobserwować wyraźne tendencje kwestionujące tak zasadność, jak i potrzebę wyróżnienia maski artystycznej jako odrębnego dobra prawnego. Pomimo to pojęcie maski od lat funkcjonuje w rzeczywistości prawnej, nieustannie skłaniając do zastanowienia się nad jego istotą. Być może źródłem tego stanu rzeczy jest fakt, że jest ono „zawieszone” pomiędzy wizerunkiem osoby fizycznej, utworem a artystycznym jakby wykonaniem, przy czym jego przyporządkowanie do jednej z wymienionych kategorii zależy zwykle od okoliczności konkretnej sprawy. Dodatkowo, za sprawą nowoczesnych technologii oraz nowych trendów w sztuce, opierających się na różnorakich formach ekspresji osobowości, pojęcie maski artystycznej zyskuje nowy kontekst. Wystarczy w tym miejscu przywołać choćby przykład tworzenia wirtualnych postaci, bazujących nie tylko na wizerunku konkretnej osoby fizycznej, ale i na jej cechach osobowości, czy też zjawisko podwójnej tożsamości, czego przykładem są kreacje następujących artystów: Petera Burna - brytyjskiego piosenkarza, który korzystał z zabiegów chirurgii plastycznej i eksperymentował ze swoim wyglądem, RuPaula Andre Charlesa - amerykańskiego wokalisty wykorzystującego sceniczny wizerunek kobiety, czy Salvii albo

${ }^{28}$ Ibidem, s. 63.

${ }^{29}$ D. Flisak, (w:) D. Flisak (red.), Prawo autorskie i prawa pokrewne. Komentarz, Warszawa 2015, s. 1143. 
Hannah Rose Dalton. Zjawisko, o którym tutaj wspominamy, obejmuje, oprócz dokonań aktorów i mimów, również wielu artystów performatywnych, kreujących wizerunek oderwany od ich naturalnego wyglądu ${ }^{30}$. Warto odnotować, że charakteryzacja, która prowadzi do zmiany ich naturalnego wyglądu, jest nie tylko niezwykle kosztowana, ale również pochłania każdorazowo wiele godzin. Artyści ci podejmują bowiem znaczny wysiłek organizacyjny, po to, aby uzyskać ostateczny efekt, który czyni ich realny obraz nierozpoznawalnym. W zaprezentowanych powyżej przypadkach rozpoznawalność osoby fizycznej jest nierzadko jedynie kontekstowa, tzn. wiadomo, że jest to konkretny artysta, bo wiemy, iż właśnie ten artysta wykreował dany wygląd. Możliwe jest jednak oderwanie wizerunku tej osoby od wizerunku postaci, którą stworzył. Ten stan rzeczy usprawiedliwia podjęcie kolejnej próby nakreślenia istoty maski artystycznej.

\section{MASKA ARTYSTYCZNA - PRÓBA ZDEFINIOWANIA POJECIA}

\section{ROZWAŻANIA OGÓLNE}

Choć pojęcie „maska artystyczna” występuje w nauce prawa od przeszło stu lat ${ }^{31}$, to do dzisiaj ani doktryna, ani orzecznictwo nie zdołały wypracować definicji, która w sposób wyczerpujący oddawałaby istotę zjawiska, dla którego określenia jest ono używane. Przyczyn tego stanu rzeczy jest zapewne wiele. Wydaje się jednak, że źródłem tych trudności jest przede wszystkim wątpliwość wyrażająca się w pytaniu, czy „maska artystyczna” odznacza się cechami na tyle swoistymi, że na płaszczyźnie teoretycznej jest uprawnione, a zarazem potrzebne z punktu widzenia praktyki, mówienie o niej jako o odrębnym typie dobra podlegającego ochronie prawnej. Inaczej mówiąc, dylemat, jaki pojawia się na tym polu, sprowadza się do pytania, czy termin „maska artystyczna” oznacza autonomiczny przedmiot ochrony, czy też przeciwnie, jest to pojęcie graniczne używane dla określenia dobra, którego w rzeczywistości nie ma, a w każdym razie nie jest ono w stopniu dostatecznym wyodrębnione. Być może maska artystyczna jest jedynie pewną formą wizerunku człowieka, a może należy łączyć ten termin, czy to $\mathrm{z}$ utworem, czy to z artystycznym wykonaniem - przedmiotami chronionymi prawem autorskim. Charakterystyczna dla maski artystycznej bliskość do

${ }^{30}$ Zob. https://www.f5.pl/fashion/post-human-mutants-nowe-gwiazdy-instagrama (dostęp: 15.06.2021 r.).

${ }^{31}$ S. Ritterman, Komentarz..., s. 120; wyrok Sądu Najwyższego z dnia 15 kwietnia 1965 r., I CR 58/65, OSPiKA 1966, nr 6, poz. 130, a w doktrynie niemieckiej A. Elster, Genießt die Maske Schutz gegen Wiedergabe der Nachahmung?, „Der neue Weg” 1931, nr 2, s. 1. 
innych dóbr prawnych sięga tak dalece, że w praktyce, na tle konkretnych stanów faktycznych, nierzadko powstaje wrażenie tożsamości treściowej. $Z$ tego powodu wyjaśnienie natury maski artystycznej należy rozpocząć od przedstawienia kilku, będących źródłem sporów sądowych, stanów faktycznych. Ich analiza stworzy odpowiedni punkt oparcia dla dalszych rozważań.

\section{KONTROWERSJE WOKÓŁ „MASKI” W WYBRANYCH SPORACH SĄDOWYCH}

Zacznijmy od jednej z najstarszych w historii judykatury spraw o maskę artystyczną, a mianowicie od sprawy Charliego Chaplina.

\section{Charlie Chaplin}

Historia sporu sądowego wywołanego z powództwa Charliego Chaplina jest doskonałym materiałem do rozważań o masce artystycznej ${ }^{32}$. Do dzisiaj powszechnie znana jest, stworzona przez komika w latach 20. minionego stulecia, fikcyjna postać włóczykija, o przyciągającym uwagę charakterystycznym wąsiku, występującego zawsze w takich samych, obszernych spodniach, za dużych butach, śmiesznym, dla odmiany za małym, meloniku, przyciasnej kamizelce i równie skąpej marynarce. Wymachujący elegancką laseczką, z sobie tylko właściwymi manierami, odpowiednią mimiką, Charlie Chaplin - ikona - szybko doczekał się naśladowców. Tak na przykład w 1920 r. jeden z producentów amerykańskich przystąpił do produkcji serii filmów z Charlesem Amadorem w roli Charlesa Aplina imitującego wykreowaną przez Charliego Chaplina, opisaną wyżej, postać. Dość powiedzieć, że już w reklamie zapowiadającej wspominaną serię na pierwszy rzut oka wyraźne było nawiązanie do słynnego włóczykija, i to nie tylko w brzmieniu imienia i nazwiska. Również pozostałe elementy kreacji świadczyły o dużym podobieństwie do oryginału, choćby takie jak ubiór, makijaż, ruchy ciała odtwórcy głównej roli. W odpowiedzi na wspomniany „plagiat" postaci, jej twórca wystąpił z powództwem do sądu i wygrał. Sąd I instancji zakazał rozpowszechniania spornego filmu, pt. The Race Track oraz pozostałych, planowanych odcinków serii. W ocenie sądu kreacja Charlesa Amadora może wywołać u publiczności błędne przekonanie, że w istocie odtwórcą roli jest sam Charlie Chaplin. I to właśnie ta okoliczność przesądziła o uwzględnieniu powództwa. Sąd dostrzegał wprawdzie proces twórczego wykreowania postaci włóczęgi, na który składają się takie elementy jak: gra aktorska, mimika, charakterystyczne ruchy ciała, zapadający w pamięć ubiór itd. Ostatecznie jednak odmówił objęcia

${ }^{32}$ Docket No. 6322 Court of Appeal of California, First District, Division Two Chaplin v. Amador 93 Cal.App. 358 (Cal. Ct. App. 1928), 269 P. 544 Decided Jul 30, 1928, https://casetext. com/case/chaplin-v-amador (dostęp: 15.06.2021 r.). 
monopolem prawnym twórcy „włóczęgi”, skupiając się wyłącznie na skutkach wykorzystania kreacji, a mianowicie na próbie oszustwa publiczności ${ }^{33}$.

\section{Btękitny Aniot}

Problem prawa do dysponowania wykreowaną postacią zarysował się również w słynnym sporze o wykorzystanie w celach reklamowych jednej ze scen filmu „Błękitny Anioł” (Der blaue Engel, w reżyserii Josefa von Sternberga z 1930 r.), ukazującej Marlenę Dietrich w prowokacyjnej pozie, podczas wykonywania piosenki: Ich bin von Kopf bis Fuß auf Liebe eingestellt. Sprawa była o tyle ciekawa, że nie doszło w niej do bezpośredniego przejęcia wizerunku aktorki, utrwalonego na kadrach filmu, lecz do, wpierw odtworzenia, a następnie sfotografowania, wspominanej sceny. Uczyniono to przy tym po wielu latach od premiery filmu, przy pomocy zatrudnionej w tym celu modelki, o podobnej urodzie, ucharakteryzowanej tak, aby przypominała Marlenę Dietrich, która wówczas już nie żyła. Zdjęcie zostało następnie wykorzystane w reklamie prasowej urządzeń kserograficznych, z wymownym dopiskiem: „Marzenie o błękitnym aniele nam nie wystarczy". W I instancji oddalono wniesione powództwo, ale już sąd odwoławczy zmienił wyrok, wychodząc z założenia, że doszło do naruszenia majątkowych aspektów prawa do wizerunku Marleny Dietrich, którego obecnymi dysponentami są spadkobiercy aktorki. U podstaw takiego rozstrzygnięcia legło przekonanie, że odtworzenie aktorki w jej roli prowadzi do naruszenia jej prawa do wizerunku, jeśli tylko może być on rozpoznawalny w „imitacji”. Dla wyjaśnienia trzeba dodać, że w Niemczech prawo do wizerunku ujmowane jest szeroko i obejmuje nie tylko odwzorowanie osoby w ścisłym tego słowa znaczeniu, ale także odwzorowanie osoby odegranej przez aktora, czy to w filmie, czy to na deskach teatru. Podkreślmy, w drugim przypadku nie chodziło o wizerunek osoby aktora, który może pozostawać rozpoznawalny, lecz o wizerunek - maskę, którą przywdziewa aktor, wcielając się w odgrywaną postać ${ }^{34}$.

\section{Eva \& Adel}

W 1997 r. niemieckie czasopismo „Die Zeit” opublikowało artykuł pod wymownym tytułem „Właściwie jesteśmy cztery”, który zawiera obszerny wywiad z parą, znaną publicznie pod pseudonimem Eva \& Adel. Publikacja została opatrzona licznymi ilustracjami ukazującymi bohaterki, wywiady w typowych dla nich ujęciach, kiedy to występują razem, jednakowo ubrane w jasnych, jaskrawych kolorach, z rzucającą się w oczy biżuterią, z ogolonymi, pomalowanymi na biało głowami oraz z charakterystycznym ostrym makijażem. Dodajmy, że para ta od lat razem uczestniczy w targach, wystawach, odwiedza muzea na całym świecie, zyskując sławę jako chodzące dzieło sztuki, nazywane przez nie-

${ }^{33}$ Jak stwierdza się w uzasadnieniu wyroku: „Equity nie zajmuje się środkami, przy pomocy których dokonuje się oszustwa, lecz jedyne skutkami, będącymi rezultatem ich zastosowania, tzn. samym oszustwem".

${ }^{34}$ Patrz H.-P. Götting, (w:) G. Schricker, U. Loewenheim, Urheberrecht, § 22 KUG, beck-online, 2020, nb 1-64. 
których wręcz ikoną sztuki nowoczesnej. Towarzyszy im motto zatarcia granicy między płcią, co znajduje wyraz w sztucznie wykreowanym artystycznym wizerunku osób tej samej płci. Same o sobie mówią, że pochodzą z przyszłości, a ich stylizacje to żywe dzieło sztuki, które nigdy się nie kończy.

Źródłem sporu sądowego były zdjęcia ilustrujące parę, które zostały załączone do wspominanego artykułu i wraz z nim opublikowane, bez upoważnienia przez bohaterki wywiadu. $Z$ powództwem o wynagrodzenie $\mathrm{z}$ tytułu bezprawnej eksploatacji praw autorskich „chodzącego eksponatu sztuki” wystąpiła agencja, której Eva \& Adel powierzyły w zarząd swoje prawa. Nie wchodząc w szczegóły, wystarczy w tym miejscu poprzestać na twierdzeniu, że sąd I instancji uwzględnił powództwo oparte na roszczeniu z tytułu naruszenia prawa autorskiego, uznając tym samym ,żywą rzeźbę” za utwór w rozumieniu prawa autorskiego. Według natomiast sądu odwoławczego, który nie podzielił tego zapatrywania, sceny z „normalnego życia” ipso iure nie mogą nosić cech duchowej twórczości. Ostatecznie powództwo oddalono, co dało doktrynie asumpt do dyskusji wokół kwestii, czy człowiek - poprzez swój wygląd, zachowanie, mimikę itp. - może tworzyć utwór, jego oryginalny egzemplarz, stworzony rzecz jasna przez niego samego ${ }^{35}$.

\section{Stefan Bak}

Interesującego materiału badawczego dostarcza również sprawa Stefana Bąka - fikcyjnego słuchacza radiowej listy przebojów - postaci, którą speaker radiowy ukształtował jako niedorajdę życiowego, o wyrazistych poglądach na świat i charakterystycznym sposobie mówienia. Stefan Bąk występował na antenie radia regularnie, dzielił się ze słuchaczami swoimi, kontrowersyjnymi nierzadko, zapatrywaniami. Jego twórca, powód w omawianej sprawie, przeprowadzał cykliczne wywiady ze Stefanem, zmieniając odpowiednio głos, w rezultacie czego powstawało wrażenie, że dialog jest prowadzony przez dwie, odrębne osoby. Proces kreacji opisanej postaci nie był oparty na żadnym przygotowanym wcześniej scenariuszu, był raczej rezultatem improwizacji, tworzonym na bieżąco, pod wpływem chwili. Postać Stefana Bąka była odtwarzana przez jego twórcę, najpierw na antenie radia Parada, później zaś w konkurencyjnej rozgłośni radiowej, do której przeszedł jego twórca. Pomimo to dotychczasowa rozgłośnia kontynuowała praktykę wystąpień barwnego słuchacza z Żabiczek, w którego wcielał się już jednak nowy pracownik stacji. Co istotne, kontynuator wzorował się na poprzedniku do tego stopnia, że dla słuchaczy odgrywana przez niego postać była wciąż tym samym Stefanem Bąkiem. Upraszczając dalsze zawiłości stanu faktycznego, wystarczy w tym miejscu poprzestać na stwierdzeniu, że Sąd Apelacyjny w Łodzi nie dostrzegł w spornej postaci cech utworu, ponieważ, jak można dowiedzieć się z uzasadnienia, opiera się ona na stereotypie, ten

${ }^{35}$ P. Raue, Eva \& Adel - der Mensch als ,,Werk” im Sinne des Urheberechtes, GRUR 2000, z. 11-12, s. 951 i n. 
zaś nie podlega autorsko-prawnej ochronie. Dla porządku dodajmy, że sprawa była rozpatrywana na podstawie ustawy o prawie autorskim z 1952 r., która nie zawierała przepisów o prawach pokrewnych artystów wykonawców. Odrzucono również zarówno koncepcję maski artystycznej, pojmowanej jako odrębne dobro, jak i możliwość ochrony pseudonimu artystycznego, argumentując, że nadane postaci fikcyjnej nazwisko było łączone wyłącznie $\mathrm{z}$ tą postacią, nie zaś z osobą jej twórcy. Z podobnych względów odmówiono ochrony przed imitacją głosu. Skoro powód, wcielając się w Stefana Bąka, zmieniał barwę i intonację swojego oryginalnego głosu, to naśladownictwo tego „sztucznego brzmienia” nie może być potraktowane jako naruszenie wizerunku, do którego elementów bez wątpienia głos jest zaliczany. Rozstrzygnięcie to zostało następnie zmienione przez Sąd Najwyższy, który uznał, że fikcyjna postać Stefana Bąka stanowi przejaw działalności twórczej o indywidualnym charakterze, co czyniło odniesienie się do zagadnienia maski artystycznej bezprzedmiotowym ${ }^{36}$.

\section{Genowefa Pigwa}

Z punktu widzenia prowadzonych rozważań warto również przypomnieć jedno $\mathrm{z}$ najbardziej znanych $\mathrm{w}$ Polsce orzeczeń dotyczących przetworzonego wizerunku scenicznego, to jest wyroku Sądu Apelacyjnego w Krakowie z dnia 7 lutego 1995 r. ${ }^{37}$. Przedmiotem sporu było wykorzystanie wizerunku scenicznego aktora Bronisława Opałki, który od lat 70. XX wieku kreował postać kabaretową Genowefy Pigwy. W powołanym wyroku sąd uznał, że karykatura wizerunku scenicznego powoda, wykorzystana na etykiecie piwa, powinna być rozważana w kontekście przepisów o ochronie dóbr osobistych. U podstaw takiego rozstrzygnięcia legło przekonanie, że etykiety piwa zawierają ,wizerunek w postaci karykaturalnej postaci scenicznej powoda oraz jego pseudonim artystyczny". Naruszenia dobra dopatrywano się w wykorzystaniu przez pozwanych „danych nierozerwalnie związanych z osobą powoda", a elementy etykiety zezwalały na „identyfikację rysunku z osobą powoda”, a zatem z jego wizerunkiem. W ocenie sądu bez znaczenia pozostawał przy tym fakt, że powód przebiera się przed występami, po to, aby odtwarzać rolę fikcyjnej postaci.

\section{WNIOSKI}

Każdy z przytoczonych przykładów może stanowić podstawę do rozważań nad istotą maski artystycznej, każdy z nich odsłania też nieco inny aspekt interesującego nas zagadnienia. I tak, przypadek pierwszy skłania do zastanowienia, czy uprawnione jest utożsamienie maski z artystycznym wykonaniem, które obecnie dość powszechnie jest obejmowane ochroną przez regulacje prawne.

${ }^{36}$ Warto odnotować również interesujące uwagi zgłoszone w: R. Kasprzyk, Glosa do wyroku SN z 3 października 2007..., s. 61-72.

${ }^{37}$ Wyrok Sądu Apelacyjnego w Krakowie z dnia 7 lutego 1995 r., I ACr 697/94, LEX nr 62626. 
Sprawa Marleny Dietrich z kolei nasuwa pytanie, czy „maskę artystyczną” można ulokować w obrębie pojęcia wizerunku, zapewniając w ten sposób ochronę także wizerunkowi „nierzeczywistej” postaci. Problem „maski artystycznej” przewija się również bardzo wyraźnie w sprawie Stefana Bąka. Analiza zarówno treści uzasadnień kolejnych rozstrzygnięć sądowych, jak i znakomitej glosy do wyroku Sądu Najwyższego, autorstwa Rafała Kasprzyka, prowadzą do spostrzeżenia, że maska artystyczna wymyka się z ram tradycyjnych dóbr, takich jak będący elementem wizerunku głos, pseudonim artystyczny, czy w końcu utwór przyjmujący postać np. fikcyjnej postaci literackiej. I w końcu głośna sprawa Eva \& Adel, której okoliczności unaoczniają problem wyrażający się w pytaniu, czy egzemplarzem utworu może być człowiek i czy w konstrukcji utworu mieści się kreacja, która choć niepozbawiona cech twórczych, stanowi jednak element życia codziennego, pewnego sposobu na życie, nawet jeśli u jego podłoża leży określone przesłanie.

Przytoczone stany faktyczne pozwalają sformułować katalog cech właściwych dla maski, który pozwoli przynajmniej w przybliżeniu wyznaczyć jej kontury. Otóż wydaje się, że zasadniczym elementem konceptu maski artystycznej jest stworzenie sztucznej, bo nierzeczywistej osoby, o określonej, często kompleksowej tożsamości. Nie chodzi przy tym o odegranie postaci, czy to scenicznej, czy to filmowej, w każdym razie nie tylko o to. Tworzenie maski artystycznej wykracza dalece poza akt artystycznego wykonania roli przez aktora, choć oczywiście w wielu przypadkach odtwarzana postać może się stać zalążkiem maski artystycznej. W naszym przekonaniu maska jest czymś więcej. Maska to „sztuczna tożsamość", której nośnikiem jest jednak nie utwór literacki (choć takiż może odegrać rolę w procesie jej tworzenia), jak to ma miejsce w przypadku postaci fikcyjnych, lecz człowiek, który stanowi żywy, bo podlegający ciągłym przekształceniom, jej materiał. W tym ujęciu maska tworzy osobowość paralelną do rzeczywistej osobowości jej twórcy. Przykłady takich „sztucznych osobowości” można mnożyć. Do wymienionych już wyżej przypadków Charliego Chaplina, Eva \& Adel, Stefana Bąka z Żabiczek, Genowefy Pigwy można dorzucić dalsze przypadki: Conchita Wurst, kreacje stworzone przez braci Marx, czy w końcu Dick i Doof.

Oczywiście, zdajemy sobie sprawę z tego, że w praktyce często mają miejsce sytuacje graniczne, zwłaszcza w przypadku ról filmowych, względnie teatralnych, nie tyle odgrywanych, co kreowanych przez aktora. Przykładem są choćby „Błękitny Anioł” w kreacji Marleny Dietrich, Larry Hagman jako J. R. Ewing w operze mydlanej „Dallas”, postać Holly Golightly z filmu „Śniadanie u Tiffany'ego" zagrana przez Audrey Hepburn, czy Kobieta pracująca stworzona przez Irenę Kwiatkowską. Naszym zdaniem, mówienie o masce artystycznej jako o odrębnej kategorii prawnej nadbiera sensu jedynie wówczas, gdy kreacja wykracza poza ramy dzieła, a jej egzystencja staje się samodzielna do tego stopnia, że zaczyna ona żyć własnym życiem. 


\section{MASKA ARTYSTYCZNA W RELACJI DO INNYCH DÓBR PRAWNYCH}

Dotychczasowe ustalenia wiodą do wniosku, że maska artystyczna ma wiele obliczy. W poszukiwaniu jej istoty przydatne wydaje się również odniesienie jej do innych dóbr, o utrwalonym już statusie prawnym, takich jak utwór, artystyczne wykonanie czy wizerunek. Być może zestawienie z tymi, dobrze znanymi przecież, kategoriami pozwoli jeszcze lepiej wydobyć cechy, które są właściwe wyłącznie dla maski.

\section{MASKA ARTYSTYCZNA A WIZERUNEK CZLOWIEKA}

Zacznijmy od oceny maski artystycznej z punktu widzenia reguł ochrony prawnej wizerunku, a zatem od wyjaśnienia, czy wizerunek, pojmowany jako dobro osobiste, wyznacza właściwą, a zarazem wystarczającą, płaszczyznę dla prawnej kwalifikacji maski artystycznej.

W niektórych porządkach prawnych zagadnienie maski artystycznej jest rozpatrywane bowiem właśnie w kategoriach prawa do wizerunku. Podejście to nie zaskakuje, ostatecznie wiele w tym względzie zależy od tego, jak pojmowany jest wizerunek. Nie od dziś wiadomo, że zarówno samo pojęcie wizerunku, jak i charakter prawa do niego od lat wywołują rozliczne kontrowersje w nauce prawa, nie tylko zresztą polskiej. Stwierdzenie to nie powinno dziwić, skoro nawet udzielenie odpowiedzi na tak podstawowe pytanie, czym jest wizerunek człowieka, do dzisiaj budzi rozliczne spory. Pojawiające się co jakiś czas nowe koncepcje albo modyfikacje dotychczasowych stanowisk są wynikiem poszukiwania rozwiązań problemów ujawniających się przede wszystkim w obrocie. To zaś, co się w nim dzieje, związane jest z kulturą i regułami życia społecznego. To właśnie podłoże społeczne i kulturowe powinno być, i jest, czynnikiem determinującym wszelkie analizy w tej materii. Wizerunek jest bowiem szczególnym dobrem, podczas którego analizy zawodzi cząstkowe odwołanie się jedynie do aksjologii, do natury człowieka albo ekonomii. Wizerunek jest „uwikłany” kulturowo - przez co mamy na myśli to, że reguły akceptowanych społecznie czynności, mających za przedmiot wizerunek człowieka (w szczególności tzw. komercjalizacja wizerunku), są zmienne w czasie oraz stanowią wypadkową, nieraz sprzecznych tendencji czy wielu zasad ogólnych. Toteż nie dziwi fakt nadawania pojęciu „Wizerunek” różnorakiej treści, podobnie zresztą sprawa ma się z formami jego naruszenia. Tytułem przykładu, dość powszechnie wizerunek człowieka wiąże się z cechami jego wyglądu zewnętrznego, pozwalającymi na jego identyfikację. W tym kontekście nie budzi żadnych oporów stwierdzenie, że rysy twarzy stanowią element wizerunku, ale już w przypadku sylwetki albo fryzury pojawiają się wątpliwości. Podobnie, można się zastanawiać, czy charakterystyczny dla danej 
osoby sposób ubierania mieści się w zakresie wizerunku. W praktyce orzeczniczej zasadnicze różnice w podejściu do wizerunku odnosi się przede wszystkim do form jego naruszenia; odrębności uwidaczniają się przede wszystkim w przypadku naśladownictwa.

Doskonałym tego przykładem jest opisana wyżej sprawa naśladownictwa Marleny Dietrich, a właściwie odtwarzanej przez nią postaci w filmie „Błękitny Anioł". Przypomnijmy, do uzasadnienia tezy o naruszeniu wizerunku wystarczył fakt naśladownictwa charakterystycznej pozy oraz ubioru aktorki, bowiem odbiorcy jednoznacznie wiązali te właśnie elementy z osobą Marleny Dietrich ${ }^{38}$.

Podobne podejście do wizerunku wykazuje również judykatura włoska. Warto w tym miejscu odnotować wyrok sądu w Turynie w sprawie wykorzystania podobizny Audrey Hepburn ${ }^{39}$. W powołanej sprawie synowie słynnej aktorki domagali się od pozwanej spółki pokaźnego odszkodowania należnego im z tytułu nieuprawnionego wykorzystania wizerunku ich matki na wyprodukowanych, a następnie wprowadzonych do obrotu koszulkach. Co interesujące, z punktu widzenia prowadzonych rozważań, na koszulkach tych widniała podobizna kobiety ubranej w czarną sukienkę, $\mathrm{z}$ diamentowym naszyjnikiem, tiarą we włosach, w dużych ciemnych okularach przeciwsłonecznych, paląca papierosa przez długą rurkę z ustnikiem. Wszystkie te elementy miały przypominać odbiorcy postać młodej i eleganckiej kobiety - Holly Golightly, głównej bohaterki filmu „Śniadanie u Tiffany’ego”, granej właśnie przez Audrey Hepburn. Wobec sformułowanych żądań pozwana w procesie broniła się m.in. przekonując, że opisany obraz nie stanowi wiernego odwzorowania wizerunku aktorki, lecz przybiera postać nowego, oryginalnego dzieła.

Nie wchodząc w szczegóły, wystarczy w tym miejscu poprzestać na stwierdzeniu, że sąd uwzględnił powództwo, potwierdzając naruszenie prawa do wizerunku nieżyjącej od lat aktorki, w sytuacji, w której odtworzona na koszulach podobizna wzbudzała skojarzenia z odgrywaną przez nią rolą filmową.

Takie podejście do wizerunku i jego ochrony tworzy jaskrawy kontrast z tym, obserwowanym w polskiej nauce (uwaga ta dotyczy zresztą nie tylko pojęcia wizerunku, ale i charakteru prawa do niego ${ }^{40}$ ). Jak wiadomo, w nauce polskiej dość

${ }^{38} \mathrm{~W}$ literaturze niemieckiej zaznacza się, że dla naruszenia prawa do wizerunku decydujące znaczenie ma rozpoznawalność przedstawionej osoby, co istotne, nie muszą być odtworzone rysy twarzy naśladowanej osoby. Przedmiotem naśladownictwa mogą być także inne cechy osobowości, byleby tylko pozwalały one na zidentyfikowanie osoby (np. typowe gesty, fryzura lub ubranie, charakterystyczna poza, a nawet przedmioty, które są typowo kojarzone z daną osobą). Patrz obszernie na ten temat: F. M. Fronius, Celebrity Impersonators im deutschen und US-amerikanischen Recht, Baden-Baden 2015, s. 278 i n.

${ }^{39}$ Sąd I instancji w Turynie, syg. 940/2019, 27.02. 2019, General Docket nr 12322/2017.

${ }^{40}$ Por. B. Giesen, O naturze prawa do wizerunku - uwagi na tle rozważań historycznych oraz prawnoporównawczych, (w:) J. Barta, J. Chwalba, R. Markiewicz, P. Wasilewski (red.), Qui Bene Dubitat, Bene Sciet. Ksiegga jubileuszowa dedykowana Profesor Ewie Nowińskiej, Warszawa 2018, s. $133-152$. 
powszechnie przez pojęcie wizerunku rozumie się ,dostrzegalne, fizyczne cechy człowieka, tworzące jego wygląd i pozwalające na identyfikację osoby wśród innych ludzi" ${ }^{\prime \prime 1}$. Naruszenie zaś przyjmuje się wówczas, gdy dochodzi do odtworzenia elementów wizerunku w stopniu umożliwiającym identyfikację tej osoby. W konsekwencji takiego ujęcia Martyna Podolska przekonuje, że wykorzystanie w reklamie wizerunku aktora, wcielającego się w postać sceniczną, nie narusza prawa do wizerunku, ponieważ „(...) w reklamie nie pojawia się on, jako osoba publiczna, znana z imienia i nazwiska, tylko jako postać fikcyjna (...)"42. Pogląd powołanej autorki w oczywisty sposób nawiązuje do wcześniejszej wypowiedzi Stefana Grzybowskiego, Andrzeja Kopffa i Jerzego Serdy. Przypomnijmy, autorzy ci o masce artystycznej mówili wówczas, gdy ,(...) objawiający się przez nią wizerunek nie ujawnia szczególnych rysów artysty, a jedynie kojarzy się z postacią przedstawianą"^3 ${ }^{9}$. Różnica widoczna jest już na pierwszy rzut oka. W przykładach z orzecznictwa niemieckiego i włoskiego pojęcie maski artystycznej jest zwykle lokowane w obrębie szeroko pojętego wizerunku człowieka. Takie podejście nie dziwi, już bowiem Josef Kohler przekonywał, że prawo do własnego wizerunku powinno obejmować również maskę teatralną aktora ${ }^{44}$. Poza tym w judykaturze państw zachodnich ocena naruszenia wizerunku jest zwykle dokonywana przez pryzmat wartości właściwych dla sfery osobowości człowieka. Przedmiotem ochrony jest osobowość jako taka. Każde z dóbr osobistych jest jedynie formą zjawiskową jej wyodrębnionego fragmentu, na ich straży stoją prawa osobistości, które stanowią gwarancję egzystencji, rozwoju oraz respektu własnej odrębności. $\mathrm{Z}$ tego względu punkt ciężkości oceny tkwi nie tyle w wiernym odwzorowaniu cudzych rysów twarzy, względnie cudzej sylwetki, ani nawet nie w stworzonej w ten sposób możliwości identyfikacji takiej osoby, ile w nieuprawnionym wtargnięciu w sferę cudzej prywatności. Skoro bowiem wizerunek stanowi element osobowości człowieka, tylko on sam może decydować o wykorzystaniu go przez innych. Stąd też zakres i sposób odtworzenia cudzego wizerunku ma znaczenie dla odpowiedzialności cywilnej o tyle, o ile ten fakt stanowi wtargnięcie w sferę osobowości poszkodowanego. Innymi słowy, istotne jest nie tyle to, który element powierzchowności człowieka jest przedmiotem odwzorowania (rysy twarzy, strój, sposób mówienia, mimika, gestykulacja), ile to, czy percepcja rozpowszechnionego obrazu umożliwia identyfikację określonej osoby fizycznej.

Jak wiadomo, w nauce polskiej dominuje wąskie ujęcie wizerunku, które ogranicza go do dostrzegalnych cech fizycznych człowieka, które tworzą jego

${ }^{41}$ E. Wojnicka, Prawo do wizerunku w ustawodawstwie polskim, „Zeszyty Naukowe Uniwersytetu Jagiellońskiego" 1990, z. 56, s. 107.

${ }^{42}$ M. Podolska, Postać fikcyjna jako przedmiot ochrony prawnoautorskiej, „Biuletyn SAWP” KUL 2018, t. XIII, 15 (2), s. 239-252.

${ }^{43}$ S. Grzybowski, A. Kopff, J. Serda, Zagadnienia prawa autorskiego, Warszawa 1973, s. 164 .

${ }^{44}$ J. Kohler, Das Eigenbild..., s. 20. 
wygląd, a jednocześnie pozwalają na identyfikację danej osoby ${ }^{45}$, choć warto odnotować, że nie brak również odmiennego, szerokiego rozumienia ${ }^{46}$. Niezależnie od przyjętej definicji wizerunku, w naszym prawie maska artystyczna nie mieści się jednak w jego ramach, choć w polskim orzecznictwie odnaleźć można również orzeczenia, które wydają się sugerować coś innego. Tytułem przykładu, w uzasadnieniu wyroku z dnia 22 lutego 2017 r. Sąd Najwyższy ${ }^{47}$, odnosząc się do pojęcia wizerunku oraz podstaw jego ochrony, stwierdza: „Ochronie podlega także sztucznie wykreowany wizerunek artysty (tzw. maska sceniczna), np. wykreowana przez aktora postać filmowa o charakterystycznym wyglądzie, o ile umożliwia ona rozpoznanie osoby kreującej wymyśloną postać (...)". Z powyższej wypowiedzi nie należy, naszym zdaniem, wyciągać zbyt daleko idących wniosków. Wprawdzie w uzasadnieniu wyroku nawiązano do pojęcia maski scenicznej, ale uczyniono to jedynie dla wykazania, że charakteryzacja do zdjęcia, jeśli tylko nie wpływa na rozpoznawalność, nie ma znaczenia dla objęcia ochroną na podstawie art. 81 pr.aut. Toteż przywołany fragment uzasadnienia wydaje się stanowić jedynie potwierdzenie tezy o ochronie wizerunku aktora wcielającego się w postać filmową lub sceniczną, i nic ponadto. Wszak sąd zestawił tę wypowiedź z wąsko pojmowanym pojęciem wizerunku człowieka.

Oczywiście takie podejście do wizerunku w prawie polskim może wzbudzać zastrzeżenia, tym bardziej że rezultatem jego przyjęcia jest nierzadko wykluczenie spoza obszaru ochrony kreacji postaci fikcyjnych, których przedstawienie nie przyjmuje formy artystycznego wykonania.

Na problem ten wskazuje w literaturze polskiej Krzysztof Felchner ${ }^{48}$. Chodzi mianowicie o wykorzystanie sztucznie wykreowanego przez aktora/mima wizerunku, niestanowiącego jednocześnie w realiach konkretnej sprawy fragmentu artystycznego wykonania utworu pantomimicznego. W naszej ocenie stanowisko to należy również rozciągnąć na efekty pracy artystów używających swego wyglądu jako środka wyrazu artystycznego. K. Felchner na uzasadnienie swojej tezy powołuje wyrok sądu krajowego w Monachium z dnia 27 lipca 2005 r. ${ }^{49}$. Powołany autor jest odmiennego zdania niż sąd w Monachium, uważa bowiem, że w tym wypadku nie mamy do czynienia z wizerunkiem danej osoby, a to

${ }^{45}$ Szerzej na temat pojęcia wizerunku w prawie polskim T. Grzeszak, Prawo do wizerunku i prawo adresata korespondencji, (w:) J. Barta (red.), System ..., s. 781-782; patrz również uzasadnienie wyroku Sądu Najwyższego z dnia 20 maja 2004 r., II CK 330/03, „Biuletyn Sądu Najwyższego” 2004, nr 11, s. 10, „Monitor Podatkowy” 2005, nr 2, s. 111.

${ }^{46}$ Tak na przykład wedle J. Sieńczyło-Chlabicz, wizerunek obejmuje wszystkie elementy identyfikujące daną jednostkę jako konkretną osobę fizyczną, eadem, Przedmiot, podmiot i charakter prawa do wizerunku, „Przegląd Ustawodawstwa Gospodarczego” 2003, z. 8.

${ }^{47}$ Wyrok SA w Warszawie z 22 lutego 2017 r., VI ACa 1781/17, LEX nr 2402439. s. 256.

${ }^{48} \mathrm{~K}$. Felchner, Choreografia i pantomima $w$ świetle prawa autorskiego, Warszawa 2012 ,

${ }^{49}$ Wyrok Landesgericht München I (Sąd Krajowy Monachium I) z dnia 27 lipca 2005 r. (sygn. 21 O 7562/05), Zeitschrift für Urheber- und Medienrecht, 2005/11, s. 848-849. 
dlatego, że odwzorowanie nie przedstawia jej realnych rysów. Na marginesie zaznaczmy, że wygląd mima na gruncie polskiej ustawy nie stanowiłby również przedmiotu ochrony z art. 85 ust. 1 pr.aut., a to $z$ uwagi na brak wykonywanego utworu. Tymczasem konieczność ochrony interesów takiej osoby wydaje się być oczywista. W istocie bowiem ich charakter nie odbiega od tych, leżących u podłoża takich dóbr osobistych jak np. wizerunek.

Nie wchodząc w tym miejscu w szczegóły, jesteśmy zdania, że w prawie polskim, teoretycznie rzecz ujmując, nie ma przeszkód, aby traktować wizerunek jako pojęcie zbiorcze, obejmujące swym zakresem zarówno wizerunek w ścisłym tego słowa znaczeniu (odwzorowanie cech zewnętrznych identyfikujących osobę fizyczną), jak i maskę artystyczną, której naruszenie obejmuje również przejęcie cech charakterystycznych dla odgrywanej fikcyjnej postaci, co nie oznacza, że taki pogląd ostatecznie prezentujemy. Nie ulega bowiem wątpliwości, że u podłoża prawa do wizerunku leżą różnego rodzaju interesy, także majątkowe ${ }^{50}$, i to niezależnie od tego, czy przedstawiona osoba została sportretowana w sytuacji prywatnej, publicznej, miejscu pracy lub w jakimkolwiek innym kontekście. Wizerunku nie można bowiem oderwać od osobowości danej jednostki, a osobowości od wizerunku. Nawet drastyczne zmiany wyglądu, podejmowane w kontekście artystycznym akty kreacji własnego wizerunku, a nawet szerzej, własnej osobowości, nie uzasadniają potrzeby odwołania się do konstrukcji maski artystycznej - wciąż mamy do czynienia z wizerunkiem. Bez znaczenia pozostaje przy tym okoliczność, czy chodzi o trwałe ${ }^{51}$, czy jedynie przemijające (choć istotne) zmiany w wyglądzie. W szerokim ujęciu wizerunek to maska, a maska to wizerunek. Czy jednak nawet tak szerokie pojęcie wizerunku jest wystarczająco pojemne dla każdego przypadku maski artystycznej? Do tego pytania powrócimy jeszcze w dalszej części opracowania.

\section{MASKA ARTYSTYCZNA A ARTYSTYCZNE WYKONANIE}

Nie ulega wątpliwości, że objęcie ochroną prawną artystycznych wykonań przyczyniło się do spadku zainteresowania konceptem maski artystycznej. Skoro bowiem kreację artystyczną uczyniono w europejskich porządkach prawnych przedmiotem prawa pokrewnego ${ }^{52}$, bezzasadne stało się poszukiwanie przestrzeni prawnej dla jeszcze jednej konstrukcji. Wspominane podejście jest

${ }^{50}$ Szerzej na ten temat B. Giesen, O naturze prawa do wizerunku - uwagi na tle rozważań historycznych oraz prawnoporównawczych, (w:) J. Barta, J. Chwalba, R. Markiewicz, P. Wasilewski (red.), Qui Bene..., s. 133-152.

${ }^{51} \mathrm{~Np}$. w postaci celowych oszpeceń, czy radykalnych form tatuażu pokrywających całe ciało.

${ }^{52} \mathrm{Na}$ temat historii ochrony artystycznych wykonań patrz S. Stanisławska-Kloc, Ancilliary performers (artistes de complement) i aktualności w sferze artystycznych wykonań, (w:) K. Szczepanowska-Kozłowska, I. Matusiak, Ł. Żelechowski (red.), Opus auctorem laudat. Księga dedykowana Profesor Monice Czajkowskiej-Dąbrowskiej, Warszawa 2019, s. 246-250. 
charakterystyczne dla nauki polskiej. Wystarczy w tym miejscu przywołać raz jeszcze podejście sądów kolejnych instancji do sprawy Stefana Bąka, przy której rozpoznaniu „maskę artystyczną” utożsamiano z artystycznym wykonaniem, nieobjętym jeszcze wówczas ochroną. W rezultacie utrwaliło się przekonanie, że przynajmniej w sytuacji typowej, jak np. ta, polegająca na wykorzystaniu wizerunku aktora filmowego utrwalonego wcześniej w utworze filmowym, brak jest potrzeby kumulatywnej ochrony artystycznego wykonania oraz wizerunku aktora, i dodatkowo jeszcze maski artystycznej. U podstaw takiego podejścia leży zapewne przekonanie, że w przypadku wykorzystania fragmentów wykonań, np. w reklamie, interesy aktora są chronione przez jego prawo osobiste w postaci szeroko rozumianego prawa do integralności wykonania (art. 86 ust. 1 pkt 1 lit. c pr.aut.). Chroni ono przed zachowaniami wypaczającymi wykonanie wskutek umieszczenia go $\mathrm{w}$ zupełnie innym kontekście ${ }^{53}$. Wprawdzie zgodnie $\mathrm{z}$ treścią powołanego przepisu konieczne jest dodatkowo wystąpienie negatywnych skutków w sferze reputacji artysty, która nie odnosi się do czci w ogólności (ta jest chroniona na podstawie art. 23 k.c.), co zawęża granice ochrony, ale taka jest po prostu intencja ustawodawcy.

Trzeba jednak zauważać, że w praktyce zdarzają się i takie stany faktyczne, w których bezprawne wykorzystanie wizerunku aktora (zdjęć z filmu) ewidentnie narusza jego interesy osobiste, inne niż te wyrażane w ogólnym pojęciu reputacji artysty. Niezależnie od tego, nierzadko dochodzi też do nieuprawnionej eksploatacji szeroko rozumianego wizerunku aktora, względnie jego artystycznego wykonania. Mamy na myśli przede wszystkim przypadki naśladownictwa artystycznego wykonania, połączone z imitacją pewnych elementów wizerunku aktora, tak jak to miało miejsce w opisanej wyżej sprawie Charliego Chaplina, Marleny Dietrich czy Audrey Hepburn. Wszak ustawa o prawie autorskim i prawach pokrewnych nie daje podstawy do zakazania naśladownictwa artystycznego wykonania, jest to bowiem co do zasady dozwolone ${ }^{54}$. Rzecz jednak w tym, że w wielu przypadkach naśladownictwo nie ogranicza się wyłącznie do wykonania, lecz obejmuje znacznie więcej. Przyjrzyjmy się raz jeszcze przytoczonym stanom faktycznym. W sprawie naśladownictwa Chaplina nie chodziło przecież

${ }^{53}$ K. Kurosz, Artystyczne wykonanie utworu. Prawa osobiste i majątkowe aktorów, muzyków i innych wykonawców, Warszawa 2014, s. 223-229; wyrok Sądu Apelacyjnego w Warszawie z dnia 11 września 2008 r., I ACa 380/08, niepubl. - dotyczący wykorzystania nagrania chóru śpiewającego podczas mszy w reklamie partii politycznej.

${ }^{54}$ M. Czajkowska-Dąbrowska, (w:) J. Barta, M. Czajkowska-Dąbrowska, Z. Ćwiąkalski, R. Markiewicz, E. Traple, Prawo autorskie i prawa pokrewne. Komentarz, Kraków 2005, s. 660. Nadal zachowuje aktualność stwierdzenie Stefana Grzybowskiego, że „chodzi tu nie o prawo do »takiego«, lecz prawo do »tego« wykonania (...). Ochronie podlega »wykonanie, nie zaś jego sposób, jego niejako schemat«" - S. Grzybowski, Artysta wykonawca i jego dzieło a zagadnienia ochrony prawnej, „Studia Cywilistyczne” 1968, t. XII, s. 37. Podobnie E. Żołnierczuk, Wokót zagadnień dóbr osobistych artysty wykonawcy, „Zeszyty Naukowe Uniwersytetu Jagiellońskiego. Prace z Prawa Własności Intelektualnej” 2003, nr 83, s. 110. 
o to, że inny aktor grał tak jak słynny komik, chodziło o coś znacznie więcej, a mianowicie o niewolnicze naśladownictwo, które mogło wprowadzić w błąd publiczność - o plagiat wykreowanej przez niego postaci, o kradzież jej image, o przejęcie cudzego dobra, które nie jest, a w każdym razie nie musi być ani utworem, ani artystycznym wykonaniem, ani nawet wizerunkiem osoby fizycznej. Do podobnych spostrzeżeń wiedzie analiza sprawy naśladownictwa „Błękitnego Anioła” oraz przypadek przejęcia wizerunku bohaterki filmu „Śniadanie u Tiffany'ego". W żadnej z wymienionych spraw nie chodziło bynajmniej ani o naruszenie więzi artysty z wykonaniem, ani o naruszenie prawa do wizerunku artysty w wąskim tego słowa znaczeniu, a jednak sądy bez wahania uwzględniły powództwo, nawet jeśli nie wchodziło w grę wprowadzenie w błąd publiczności. Stało się tak, gdyż naruszyciele chcieli wykorzystać tę konkretną maskę i osobowość, a nie taką maskę (jedynie podobną czy zbliżoną).

Niestety w polskiej judykaturze maska artystyczna nie jest już tak pojemną konstrukcją.

Owszem, nie neguje się prawa aktora do rozpowszechniania swego wizerunku, nawet wówczas, gdy publiczności kojarzy się on wyłącznie z odgrywaną przez niego postacią. Zasadnicze znaczenie w tym względzie ma wyrok Sądu Najwyższego z dnia 20 maja 2004 r. ${ }^{55}$. Jego uzasadnienie jest przykładem szerokiego ujęcia wizerunku. Według słów składu orzekającego „wizerunek powoda, ukształtowany i utrwalony $\mathrm{w}$ następstwie rozpowszechnienia artystycznego wykonania znanej roli, odznacza się cechami pozwalającymi mu funkcjonować w oderwaniu od osoby". W istocie wypowiedź ta w połączeniu z towarzyszącym jej szerokim ujęciem wizerunku, bo obejmującym nie tylko cechy fizyczne, lecz również „dodatkowe utrwalone elementy związane z wykonywanym zawodem jak charakteryzacja, ubiór, sposób poruszania się i kontaktowania z otoczeniem", tworzy właściwy punkt wyjścia do dogmatycznego uzasadnienia maski artystycznej.

Bez wątpienia zasadnicze znaczenie w tym względzie ma fakt teoretycznego rozróżnienia pomiędzy artystycznym wykonaniem a wizerunkiem aktora. Takie podejście, choć w pełni uzasadnione, nie czyni, jak się wydaje, zadość potrzebie ochrony usprawiedliwionych interesów twórców. Najlepszym tego dowodem jest podejście sądów polskich do naśladownictwa maski artystycznej. Weźmy na przykład rozstrzygnięcie w sprawie wykorzystania postaci Nikodema Dyzmy, którą w wersji filmowej stworzył Roman Wilhelmi ${ }^{56}$. Przypomnijmy, w przywołanej sprawie naruszenie polegało m.in. na rozpowszechnieniu stylizowanego wizerunku aktora w roli Nikodema Dyzmy oraz na radiowym nadawaniu fragmentów ścieżki dialogowej filmu pt. „Kariera Nikodema Dyzmy”, zawierających głosową warstwę wykonania roli. W niniejszej sprawie sąd w zasadzie nie podejmował zagadnienia maski artystycznej, skoro, jak wynika z treści uzasad-

${ }^{55}$ Wyrok Sądu Najwyższego z dnia 20 maja 2004 r., II CK 330/03, LEX nr 686639.

${ }^{56}$ Wyrok Sądu Apelacyjnego w Warszawie z dnia 25 sierpnia 2004 r., VI ACa 27/04, „Apelacja. Orzecznictwo Sądu Apelacyjnego w Warszawie” 2005, nr 3, s. 24. 
nienia, nie łączył w całość wizerunku aktora, a właściwie wizerunku postaci, którą on odgrywa, ze ścieżką dźwiękową filmu. Zwróćmy uwagę, dla sądu są to dwa odrębne, niezespolone ze sobą elementy - wizerunek, którego ochrona wygasła wraz ze śmiercią aktora, oraz artystyczne wykonanie będące przedmiotem prawa pokrewnego. W rezultacie naśladownictwo (plagiat) maski artystycznej Nikodema Dyzmy stworzonej przez Romana Wilhelmiego pozostało bez konsekwencji prawnych. Takie podejście jest zgoła odmienne od stanowiska sądów w Europie Zachodniej, w sprawach takich jak te wytoczone z powództwa spadkobierców Audrey Hepburn czy Marleny Dietrich.

Powyższa analiza wiedzie do stwierdzenia, że sądy polskie mają tendencje do utożsamiania maski artystycznej z artystycznym wykonaniem, względnie Z wizerunkiem aktora. Z tej perspektywy termin „maska artystyczna” niestety zatracił częściowo swoje pierwotne znaczenie i w chwili obecnej w nauce polskiej funkcjonuje on raczej jako środek doprecyzowania, że chodzi o wygląd aktora podczas jego pracy.

Dodatkowo, dominuje przekonanie, zgodnie z którym w przypadku pojedynczych zdjęć aktorów z filmu, wykorzystanych następnie np. do reklamy, brak jest podstaw do odwoływania się do konstrukcji maski artystycznej, a raczej wizerunku aktora (zapewne z uwagi na pochłonięcie wizerunku przez artystyczne wykonanie). Na marginesie odnotujmy, że takie podejście ma jeden słaby punkt. Dla jego przyjęcia konieczne jest bowiem uznanie, że pojedynczy kadr filmu - fotos filmowy - również stanowi fragment artystycznego wykonania, do którego stosujemy art. 86 pr.aut. To zaś wywołuje poważne wątpliwości w nauce prawa. W piśmiennictwie polskim, inaczej niż np. w prawie francuskim, większość autorów zajmuje bowiem stanowisko zdecydowanie negujące możliwość uznania pojedynczego fotosu (w przeciwieństwie do większej części) za fragment wykonania ${ }^{57}$. Jako podstawę rozstrzygnięć wskazują wówczas przepisy o wizerunku $^{58}$ albo właśnie konstrukcję maski artystycznej ${ }^{59}$ - scenicznego wizerunku aktora, który jednak w judykaturze nie jest traktowany jako odrębne dobro niematerialne. Na poparcie tezy o braku możliwości odwołania się do przepisów o artystycznym wykonaniu powoływany bywa wyrok Sądu Najwyższego z dnia 20 maja 2004 r. $^{60}$, w naszej ocenie jednak błędnie.

${ }^{57}$ M. Czajkowska-Dąbrowska, Prawa artystów wykonawców, (w:) J. Barta (red.), System Prawa Prywatnego. Tom 13. Prawo autorskie, Warszawa 2017, s. 503; D. Flisak, (w:) D. Flisak (red.), Prawo..., s. 1168; A. Matlak, Cywilnoprawna ochrona..., s. 323; T. Grzeszak, Prawo do wizerunku i prawo adresata korespondencji, (w:) J. Barta (red.), System..., s. 794.

${ }^{58}$ T. Grzeszak, Prawo do wizerunku i prawo adresata korespondencji, (w:) J. Barta (red.), System..., s. 794.

${ }^{59}$ A. Matlak, Cywilnoprawna ochrona..., s. 323.

${ }^{60}$ Wyrok Sądu Najwyższego z dnia 20 maja 2004 r., II CK330/03, LEX nr 686639 - tak T. Grzeszak, Prawo do wizerunku i prawo adresata korespondencji, (w:) J. Barta (red.), System..., s. 794 . 
W nauce polskiej nie brak wypowiedzi postulujących objęcie ochroną za pomocą prawa do artystycznego wykonania pojedynczych kadrów ${ }^{61}$. Stanowisko to jest trafne, gdyż brak jest podstaw do odróżnienia reżimu ochrony w zależności od tego, czy chodzi o np. dwusekundowy fragment czy stop-klatkę. W przypadku artystycznych wykonań ochrona nie jest uzależniona, tak jak w przypadku utworów, od poziomu oryginalności czy indywidualności. Nie występuje zatem problem granicznego ładunku oryginalności fragmentu dla objęcia go ochroną. Są to już jednak zagadnienia odrębne, wykraczające poza ramy wyznaczone tematem prezentowanego opracowania.

\section{MASKA ARTYSTYCZNA A UTWÓR}

Wyjaśnienie natury prawnej maski artystycznej wymaga również odniesienia tego pojęcia do dzieła chronionego prawem autorskim. Potrzebę taką unaoczniają choćby przytoczone na wstępie stany faktyczne, jak na przykład sprawy Eva \& Adel czy Stefana Bąka. Zdarza się bowiem, że kreowana postać jest czymś więcej aniżeli odtwórczym, acz artystycznym wykonaniem fikcyjnej postaci, która zawdzięcza swoje istnienie literackim umiejętnościom innej osoby, np. scenarzysty, albo noszącej znamiona twórczości gry aktorskiej. Nierzadko zresztą maska jest tworzona spontanicznie, w odpowiedzi na potrzebę chwili - tak jak to miało miejsce w przypadku barwnej postaci Stefana Bąka. Zdarza się też, że maska jest swego rodzaju happeningiem, czy też zostaje wplecionym w codzienne życie performance, jak w przypadku pary Eve \& Adel.

Pytanie o to, czy maska artystyczna może być kwalifikowana jako utwór, wyłania się zresztą w znacznie szerszym kontekście aniżeli ten wyznaczony specyfiką powołanych przypadków. W proces tworzenia fikcyjnych postaci w coraz szerszym stopniu zaprzęgana jest technologia cyfrowa, czego rezultatem są nie tylko interesujące medialnie zjawiska, jak to polegające na „kradzieży” cudzej osobowości ${ }^{62}$, ale też zagadnienia prawne, które zmuszają do ponownego przemyślenia prawnej koncepcji „,maski artystycznej”. Jak sądzimy, nie wzbudza żadnego oporu twierdzenie, że stworzona „maska” może posiadać cechy utworu, jeśli

${ }^{61}$ K. Kurosz, Artystyczne..., s. 269, oraz 206, tak również TGI Paris, 22 mai 2002, RG 02/55187, RIDA 195/2003, s. 316, z powołaniem się na wyrok Sądu Okręgu w Paryżu z dnia 22 maja 2002 r. W wyroku tym udzielono ochrony aktorowi, którego zdjęcie, bez opatrzenia nazwiskiem, wykorzystano w książce poświęconej dokonaniom jednego z reżyserów. Zdjęcie będące przedmiotem sporu przedstawiało powoda w głównej roli, specjalnie dla niego dedykowanej. Sąd uznał, że artyście wykonawcy przysługuje swoboda oznaczenia wykonania nazwiskiem wykonawcy, nawet jeżeli jest wykorzystany nieznaczny fragment wykonania (pojedynczy fotos).

${ }^{62}$ Patrz szerzej M. Lausen, Der Schauspieler und sein Replikant, "Zeitschrift für Urheberund Medienrecht" 1997, z. 2, s. 86, a także Yin Hark Lee, Putting a face to the game: the intellectual property implications of using celebrity likenesses in videogames, "GRUR International" 2017, No 11, s. 921-1009. 
tylko odpowiada ona przesłankom wskazanym w art. 1 pr.aut. Zapewne będzie tak wówczas, gdy przedstawia ona formę stadialną utworu literackiego. W takich przypadkach kreacja artystyczna nie wykracza zwykle poza ramy artystycznego wykonania, ale zdarza się, że właśnie wykracza ona poza jego ramy, dając zaczątek masce artystycznej, rozumianej jako sztucznie wykreowana tożsamość.

$\mathrm{Z}$ jurydycznego punktu widzenia znacznie ciekawiej prezentuje się jednak pytanie, czy maska, sama w sobie, może stanowić utwór, a jeśli tak, to jakiej kategorii. Wątpliwość ta nie pozostaje w sprzeczności z wcześniejszym stwierdzeniem, że maska może mieć cechy utworu, gdyż nie implikuje ono jeszcze ostatecznej konkluzji. Istota problemu sprowadza się bowiem do pytania, czy w ogóle człowiek może być egzemplarzem utworu? Jak wiadomo, utwór jest dobrem niematerialnym, który może, choć nie musi, być wyrażony w nośniku materialnym. Teoretycznie rzecz ujmując, można uciec od rozwiązania przedstawionego dylematu, przyjmując, że w przypadku maski brak jest po prostu nośnika materialnego. Taki sposób postawienia zagadnienia popadałby jednak w wewnętrzną sprzeczność. Skoro nośnik - ciało i osobowość - jest źródłem niektórych elementów maski i przez to jest w nią wpleciony, to jednocześnie nie można twierdzić, że utwór - maska - istnieje tylko w postaci idealnej. Mówiąc jeszcze inaczej - nie da się zanegować istnienia nośnika materialnego - człowieka - bez jednoczesnej negacji dobra niematerialnego.

Poszukując odpowiedzi na interesującą nas kwestię, należy zwrócić uwagę, że problem ten nie jest nowy. Idea traktowania człowieka jako swojego rodzaju nośnika utworu znana jest od wieków. Warto przypomnieć choćby o popularnej w XIX w. rozrywce przedstawiania antycznych figur, scen z życia mistrzów, czy tworzenia tzw. żywych obrazów lub rzeźb ${ }^{63}$. Wystarczy w tym miejscu przywołać przykład kreacji stworzonych przez tandem Gilbert Prousch i George Passmore. Również dla współczesnej sztuki performers charakterystyczna jest tematyzacja człowieka poprzez zespolenie jego ciała $\mathrm{z}$ utworem. W związku z tym zarówno w literaturze przedmiotu, jak i w orzecznictwie stawia się pytanie, czy wizerunek człowieka może być utworem ${ }^{64}$. Podkreślmy, nie chodzi o to, czy akt utrwalenia wizerunku - fotografia, kadr filmu, rzeźba lub obraz - jest utworem, ale o to, czy utworem może być sam odwzorowywany w ten sposób obiekt. Co istotne, przedmiotem oceny miałyby być przy tym nie tyle poszczególne elementy, czy to składające się na wizerunek, czy to stanowiące jego istotne uzupełnienie, takie jak: makijaż, fryzura, tatuaż czy charakterystyczna garderoba, ile całość, którą one w połączeniu z cechami fizycznymi tworzą.

Oczywiście, nie twierdzimy, że maska artystyczna jest tożsama z wyglądem fikcyjnej, bo sztucznie wykreowanej postaci. Tworzy ją bowiem cały zespół cech

${ }^{63}$ Podaję za P. Raue, Eva \& Adel-der Mensch..., s. 952.

${ }^{64}$ Pytanie to zostało bardzo wyraźnie postawione przez sąd I instancji w Hamburgu rozpoznający sprawę Eva \& Adel, LG Hamburg ZUM 1999, 658. Do kwestii tej odnosi się również obszernie P. Raue, Eva \& Adel-der Mensch..., s. 956. 
wyróżniających taką postać, zarówno tych zewnętrznych, jak np. jej wygląd czy sposób poruszania się, jak i cechy charakteru, sposób formułowania swoich przekonań itp. Zasygnalizowana kwestia nabiera szczególnego znaczenia w przypadku bezprawnego przejęcia cudzej maski, jak to miało miejsce w sprawie Eva \& Adel czy Genowefy Pigwy, gdzie przejęcie ogranicza się do wybranych elementów postaci kabaretowej i bazuje raczej na skojarzeniu, nie zaś na dosłownym odniesieniu.

Powróćmy jednak do pytania, czy maska artystyczna może być utworem autorsko-prawnym. Otóż wydaje się nam, że nie można na nie udzielić jednoznacznej odpowiedzi. Wiele zależy od przyjętego znaczenia maski. W prezentowanych rozważaniach wychodzimy z założenia, że maska jest konstrukcją, w której skład zwykle wchodzi zespół elementów, takich jak np. charakter wykreowanej postaci, jej głos, sposób poruszania się, formułowania i wyrażania myśli, światopogląd, sposób ubierania, krótko rzecz ujmując: wszystko to, co nadaje piętno indywidualizmu osobie fizycznej, z tą jednak różnicą, że w przypadku maski artystycznej chodzi o odgrywaną postać, o jej sztucznie wykreowaną powierzchowność oraz osobowość. Jak się wydaje, to właśnie ta wielowarstwowość jest źródłem trudności w ocenie maski z punktu widzenia kryteriów przewidzianych w art. 1 pr.aut. Nie budzi bowiem wątpliwości stwierdzenie, że utworem mogą być elementy garderoby, makijaż, monolog, choćby był on spontanicznie stworzony w trakcie prezentacji. Ale czy utworem jest maska pojmowana jako całość? Odpowiedź pozytywna wiedzie do stwierdzenia, że człowiek - będąc kreatorem maski - jednocześnie staje się egzemplarzem dzieła. Nie chodzi przy tym o to, że jego ciało jest nośnikiem utworu, jak ma to miejsce w przypadku tatuażu czy pantomimy, lecz o to, że jego wygląd, sposób bycia, jego maniery i sposób myślenia z jednej strony stanowią akt kreacji, z drugiej jednak nie są niczym więcej jak tylko sztucznie wykreowanym żywym obrazem istoty ludzkiej. W ujęciu doktrynalnym utwór nie jest wszak tożsamy z osobowością twórcy, choć jest jej emanacją. Utwór posiada bowiem byt odrębny od samego twórcy. Nie bez przyczyny powiada się, że istota autorstwa tkwi w więzi łączącej utwór z jego twórcą. Pomimo bowiem wyraźnego odniesienia do osoby twórcy więź ta jest bardziej faktem w sferze zjawisk zewnętrznych aniżeli wartością utożsamianą z pojęciem osobowości ludzkiej. Ponieważ jej drugim ogniwem jest dzieło, które tworzy byt niezależny od jego twórcy, więź ta do pewnego stopnia staje się niezależna od osoby twórcy i z tego właśnie powodu nie może być ona utożsamiana $\mathrm{z}$ jego dobrami osobistymi ${ }^{65}$. Toteż trudno upatrywać się w masce cech właściwych dla utworu.

Maska jest bowiem uzewnętrznieniem osobowości człowieka, choć sztucznie wykreowanej, to jednak osobowości realnej istoty - osoby człowieka. Wiele, żeby

${ }^{65}$ B. Giesen, Wykonywanie autorskich praw osobistych po śmierci twórcy, „Zeszyty Naukowe Uniwersytetu Jagiellońskiego" 2015, z. 128, s. 39. 
nie powiedzieć wszystko, wyjaśnia już etymologia pojęcia osoby (łac. persona). Jak podaje J. Stagl, ma ono dwa źródła. „Wedle pierwszego wyraz ten pierwotnie oznaczał też maskę, pochodzi od czasownika per-sonare, czyli »wybrzmieć«. Drugie źródło to etruskie słowo phersu, które samo w sobie zapewne znaczy "maska«". Podążając tokiem rozważań J. Stagla, skoro osoba „nie stanowi żadnej oczywistości ludzkiego bytu, ale osiągnięcie kulturowe", maska artystyczna jest więc niczym innym, jak wyrazem nie własnej, lecz wyobrażanej osobowości ${ }^{66}$. $\mathrm{W}$ podobnym duchu, lecz na innym obszarze badawczym i znacznie wcześniej wypowiada się o roli maski Edward Craing, wedle którego maska jest jedynym środkiem, aby nadać realny kształt stanowi duchowemu człowieka ${ }^{67}$.

Wskazana powyżej dwoistość terminu ,maska” ujawnia jej istotę. Konstatacja ta wiedzie bowiem do postawienia znaku równości pomiędzy tym, co rzeczywiste, tj. osobą człowieka i jego osobowością, a maską, która choć realna, to stanowi efekt sztucznej kreacji. W ten sposób następuje zatarcie granicy pomiędzy bytem rzeczywistym a wykreowanym. Maska jawi się więc jako zjawisko zawieszone pomiędzy sferą osobistości człowieka a sztuczną kreacją. Stanowi z jednej strony odbicie osobowości jej twórcy, a z drugiej strony projekcję wyobrażanej osobowości. W takim ujęciu maska wydaje się czymś więcej aniżeli jedynie utworem w sensie twórczej kreacji fikcyjnej postaci takich jak np. Sherlock Holmes, Asterix, czy znana nam z serialu „Czterdziestolatek” Kobieta pracująca. Maska artystyczna jest kreacją ,żyjącej fikcyjnej osoby" - łączącej w sobie cechy utworu i rzeczywistej osoby zarazem.

W naszej ocenie konstatacja ta odgrywa istotną rolę, a to dlatego, że otwiera drogę do twierdzenia o możliwości ochrony elementów osobowości - przetworzonej osobowości - raczej w obrębie kategorii praw osobistych aniżeli przy wykorzystaniu konstrukcji prawa autorskiego. W tym sensie maska jawi się jako coś więcej niż utwór. W naszej ocenie kreacja osobowości stanowi najdalej idącą formę przetworzenia rzeczywistości.

\section{MASKA ARTYSTYCZNA JAKO ODRĘBNA KATEGORIA PRAWNA}

Prowadzone wyżej rozważania wiodą do wniosku, że maska artystyczna wymyka się tradycyjnym kategoriom o ustalonej od dawna konotacji prawnej, takim jak: wizerunek, artystyczne wykonanie czy utwór. Wizerunek przedstawia bowiem osobowość odbitą zawsze w jakimś przedmiocie materialnym - zdjęciu, obrazie, rzeźbie. Obiekt ucieleśniający wizerunek jest w tym przypadku wtórny.

\footnotetext{
${ }^{66}$ J. F. Stagl, Persona..., s. 256 i n.

${ }^{67}$ E. G. Craig, The Actor..., s. 9.
} 
Kwintesencją wizerunku pozostaje zawsze osoba, bowiem wizerunek jest niczym innym jak cechą ją identyfikującą. Z kolei utwór, choć stanowi emanację osobowości, to jednak jest on wyłącznie obiektem zewnętrznym wobec osoby autora, jest „tylko" rezultatem jego osobowości. W przypadku utworu kwestia autorstwa schodzi w istocie na dalszy plan, skoro obojętne jest to, kto jest twórcą.

Nietrudno dostrzec, że w masce artystycznej natomiast te dwa elementy: osobowości i medium, mieszają się, a mówiąc dokładniej, ich rola jest odwrócona. Wszystko to, co tworzy tożsamość, a zatem takie elementy jak charakter czy wygląd, nie jest rzeczywiste, lecz sztucznie stworzone - w tym sensie tożsamość maski jest utworem. Inaczej natomiast niż w przypadku wizerunku nośnikiem tego „utworu” nie jest przedmiot materialny, lecz osoba. W masce człowiek staje się zatem medium sztucznej tożsamości. W przypadku maski sztucznie wytworzony wizerunek nie identyfikuje postaci realnej, lecz fikcyjną.

Wobec przedstawionych odmienności, być może zasadne jest lokowanie maski raczej w ramach całkowicie odrębnego dobra niematerialnego albo odrębnego dobra osobistego człowieka.

Odpowiedź na postawione pytanie nie jest sprawą prostą, z wielu zresztą powodów. Bez wątpienia już na pierwszy rzut oka dostrzegalna jest bliskość maski artystycznej kategorii dóbr osobistych człowieka. Nie bez przyczyny przecież w wielu ustawodawstwach jest ona utożsamiana $\mathrm{z}$ wizerunkiem człowieka, oczywiście w szerokim jego ujęciu. Rzecz jednak w tym, że w nauce polskiej nadal dominuje dość wąskie jego ujęcie, co zresztą już od dawna wydaje się być stanowiskiem odbiegającym od aktualnego stanu nauki światowej, a poza tym jest źródłem problemów w ocenie prawnej wielu sytuacji, np. tych, w których naturalny wygląd człowieka ulega tak daleko idącym, i co ważne, chwilowym przeobrażeniom do tego stopnia, że staje się on nierozpoznawalny. Takie podejście przyczynia się również do trudności z zagwarantowaniem ochrony w przypadku przejęcia jedynie pewnych elementów cudzej zewnętrzności, niekoniecznie zresztą tych fizjonomicznych. Problem ten ujawnił się w Polsce chociażby w sprawie Genowefy Pigwy czy Stefana Bąka.

Nie wchodząc w tym miejscu w szczegóły, wystarczy stwierdzić, że koncepcja traktująca maskę jako odrębne od wizerunku dobro osobiste nie jest pozbawiona podstaw. Skoro istotą dóbr osobistych jest ich ścisły, nierozerwalny wręcz związek ze sferą osobowości człowieka, to maska musi jawić się jako typowy element jej struktury. Dobitnym tego przykładem jest przypadek Eva \& Adel. Czyż obrana przez tych dwoje ludzi maska nie jest właśnie wyrazem ich duchowych potrzeb, dowodząc jednocześnie duchowej integralności pomiędzy nimi a uzewnętrznianym obrazem? Koncepcja ta ma jednak również słabe punkty.

Przyporządkowanie maski artystycznej do grupy dóbr osobistych wysuwa mianowicie na plan pierwszy niemajątkowe interesy leżące u podłoża tego dobra. Tymczasem, jak się nam wydaje, równie istotny jest majątkowy komponent maski, zwłaszcza w praktyce jej komercyjnego wykorzystania. Widać 
to wyraźnie niemalże we wszystkich przytoczonych już wcześniej sprawach. Eksploatacja sfery majątkowej jest nierzadko wysuwana wręcz na plan pierwszy. Oczywiście argument ten traci nieco na znaczeniu, jeśli zważy się na coraz wyraźniejszą w prawie polskim tendencję do dualistycznego ujmowania praw osobistości, respektującego ich aspekty tak czysto duchowe, jak i majątkowe ${ }^{68}$. Jak się wydaje jednak, wspominane interesy majątkowe, które niewątpliwie leżą u podłoża ekonomicznej eksploatacji maski, nie determinują charakteru tej konstrukcji, a w każdym razie nie na tyle, aby w stopniu dostatecznym ,przyćmić” jej odniesienie do sfery osobowości człowieka. Maska, również ta artystyczna, jest bowiem nierozerwalnie związana z osobą, stanowi jej integralną część. Dlatego wyzbycie się jej jest a priori wykluczone, to zaś ostatecznie przypieczętowuje wniosek o zasadności zaszeregowania jej do kategorii dóbr osobistych. Sprawą otwartą jest, czy stanowi ona swoiste, odrębne od innych uznanych do dzisiaj, dobro, czy też może z powodzeniem można i należy ją lokować w obrębie wizerunku człowieka. To drugie rozwiązanie wymagałoby jednak zasadniczej weryfikacji przyjmowanego przez naukę polską pojęcia wizerunku i przyjęcia jego szerokiego ujęcia tak jak to czyni się np. w Niemczech czy we Włoszech. Nie ma bowiem żadnych powodów, aby pozbawić maskę artystyczną ochrony, niezależnie od tego, czy możliwe jest jej uzyskanie na podstawie przepisów ustawy o prawie autorskim i prawach pokrewnych, bo maska artystyczna nie może i nie powinna być utożsamiana ani $\mathrm{z}$ utworem, ani $\mathrm{z}$ artystycznym wykonaniem. Maska jest elementem osoby człowieka i dlatego jest ona dobrem osobistym. Naszym zdaniem wykazuje ona bowiem wystarczająco dużo cech świadczących o jej odrębności względem wizerunku, aby mówić o niej jako o odrębnym dobrze osobistym. Jego odrębność polega również na tym, że w swobodę decydowania o losach maski i wykreowanej przy jej pomocy osobowości wplecione są również interesy majątkowe. Będąc jednocześnie dobrem osobistym - odzwierciedlenie tego, czym człowiek jest, dobro to jest jednocześnie tym, co człowiek ma ${ }^{69}$. Maska artystyczna jest zatem nie tylko odrębnym dobrem osobistym, lecz także dobrem osobistym, które może i powinno być ujmowane jako dobro o podwójnej naturze - osobistej (idealnej) i majątkowej.

${ }^{68}$ Szerzej na ten temat B. Giesen, O naturze prawa do wizerunku - uwagi na tle rozważań historycznych oraz prawnoporównawczych, (w:) J. Barta, J. Chwalba, R. Markiewicz, P. Wasilewski (red.), Qui Bene..., s. 133-152, a zwłaszcza s. 147 i 150-151.

${ }^{69}$ Nawiązujemy w ten sposób do wciąż aktualnego i przenikliwego określenia Fryderyka Zolla, który prawa osobiste charakteryzował jako chroniące nie przed „,naruszeniem tego, co człowiek ma, lecz tego czem jest" - F. Zoll, Prawa osobiste w zarysie ze stanowiska prawa prywatnego austriackiego, „Czasopismo Prawno-Ekonomiczne” 1903, R. IV, z. 1-4, s. 537. 


\section{PODSUMOWANIE}

Tworzenie maski artystycznej dalece wykracza poza akt artystycznego wykonania roli przez aktora. Wszak twórca maski nie wykonuje żadnego utworu - on kreuje osobowość. Oczywiście, nie można wykluczyć, że artystyczne wykonanie jest zalążkiem, początkiem kreacji maski artystycznej wykorzystywanej przez aktora w procesie odgrywania roli. Maska artystyczna jednakowoż wykracza w swej egzystencji poza proces wykonywania utworu.

Maska nie powinna być też utożsamiana ani z wizerunkiem, ani z utworem. Sens wizerunku wyraża się bowiem przede wszystkim w identyfikacji danej osoby, wizerunek jest cechą jej osobowości. Z kolei utwór, choć stanowi emanację osobowości, to jednak jest wyłącznie obiektem zewnętrznym wobec osoby autora, jest ,jedynie" rezultatem, swego rodzaju medium jego osobowości. Te dwa elementy, a mianowicie osobowości oraz medium, są dostrzegalne również w masce, z tym zastrzeżeniem jednak, że występują one w niej niejako w lustrzanym odbiciu. Wszystko to, co składa się na tożsamość maski, a zatem takie elementy jak charakter, wygląd, nie jest rzeczywiste, jak to ma miejsce w przypadku realnego wizerunku człowieka, lecz sztucznie stworzone.

Inaczej niż ma to miejsce zwykle w przypadku podlegającego autorskoprawnej ochronie utworu, nośnikiem maski nie jest przedmiot materialny, lecz osoba. Można powiedzieć, że w przypadku maski człowiek jest oryginalnym egzemplarzem „utworu”. Dlatego maska nie może być pojmowana jako dzieło idealne, pozbawione nośnika. Prawo autorskie do własnej osoby jest zaś pojęciowo wykluczone. W tym ujęciu maska tworzy osobowość paralelną do rzeczywistej osobowości jej twórcy.

Wiele wskazuje na to, że maska artystyczna jest dobrem szczególnego rodzaju. Najbliżej mu do dóbr osobistych, bez wątpienia jednak w ramach tej kategorii maska zajmuje odrębne miejsce. W konstrukcji maski artystycznej przeplatają się bowiem sfera osobowości i przedmiotu kreacji. W ten sposób możliwa staje się ochrona wymyślonej osobowości człowieka - ale właśnie jako osobowości człowieka, a nie utworu czy artystycznego wykonania.

Maska to „sztuczna tożsamość”, której nośnikiem jest jednak nie utwór literacki, jak to ma miejsce w przypadku postaci fikcyjnych, lecz człowiek, który stanowi żywy, bo podlegający ciągłym przekształceniom, jej materiał. W tym ujęciu maska tworzy osobowość paralelną do rzeczywistej osobowości jej twórcy. Mówiąc jeszcze inaczej, maska artystyczna jest dobrem osobistym, którego substratem jest sztucznie wykreowana lub przetworzona osobowość oraz jej fizyczne odzwierciedlenie, nieograniczające się jedynie do cech fizycznych postaci - lecz wszelkich „silnych” konotacji z osobowością (zachowanie, styl ubioru itp.).

Prowadzone rozważania $\mathrm{z}$ jednej strony prowadzą do wniosku o fundamentalnym znaczeniu woli uprawnionego w decydowaniu o tym, jak maska 
jest wykorzystywana (w przeciwieństwie do utworu i rozbudowanych regulacji dozwolonego użytku). Z drugiej strony w pewnym sensie hybrydalny status maski artystycznej wskazuje na konieczność objęcia jego ochroną również interesów majątkowych. Maska artystyczna pomimo swej odrębności od artystycznego wykonania ma z nim jedną wspólną cechę. W niektórych wypadkach (w zależności od konkretnego rodzaju maski) możliwa jest jej majątkowa eksploatacja - całości sztucznie wykreowanej osobowości, w oderwaniu od prawdziwej, wyjściowej osobowości kreatora maski. Wydaje się zatem nam całkowicie oczywiste, że muszą istnieć mechanizmy, które umożliwiają kreatorowi maski artystycznej dysponowanie nią, przynajmniej przy wykorzystaniu konstrukcji licencji, gdyż zabieg ten nie narusza godności człowieka - rdzenia ochrony dóbr osobistych. Przez dysponowanie maską człowiek nie wyzbywa się przecież swojej wyjściowej osobowości. Ów szczególny, hybrydalny charakter tego dobra osobistego polega na tym, że maska artystyczna jest jednocześnie - parafrazując wcześniej przytoczoną wypowiedź F. Zolla - tym, czym człowiek jest (w danym momencie - wchodząc w odgrywanie wykreowanej lub przetworzonej osobowości), i tym, co człowiek ma (gdy w danym momencie nie wykorzystuje maski artystycznej). Maska artystyczna jest zatem nie tylko odrębnym dobrem osobistym, lecz także jedynym dobrem osobistym, które niekiedy można oderwać - jeśli taka jest wola kreatora maski - od człowieka. Nie sposób jednocześnie w pełni oderwać maski od osobowości jej twórcy, w tych sytuacjach, gdy przetworzenie wyjściowej osobowości nie jest daleko idące, a spod maski przebłyskuje wizerunek. To zatem prowadzi do ostatniego wniosku, że możliwość oderwania maski od jej twórcy kreatora - jest stopniowalna - w zależności od stopnia przetworzenia osobowości.

Maska artystyczna wydaje się zatem dobrem osobistym o naturze jeszcze bardziej przesuniętej w kierunku dualizmu elementów osobistych i majątkowych ochrony niż wizerunek, o naturze hybrydalnej i niejednolitej.

W naszym przekonaniu zagadnienie maski artystycznej nie stanowi anachronizmu, artefaktu czasów poszukiwania podstaw ochrony artystów wykonawców. Zwłaszcza teraz, w okresie rozkwitu wielu płaszczyzn dyskusji na temat rozwoju własnej osobowości, kreacji siebie oraz tego, jak przedstawiamy się innym oraz jak dalece sięgamy w decydowaniu o tym, jak bywamy określani i nazywani. $\mathrm{Z}$ tego też powodu pojęcie maski artystycznej zaczyna być coraz bardziej interesujące. Kieruje ono bowiem naszą uwagę na obszar przenikania się sfery niematerialnej i materialnej, niemajątkowej i majątkowej.

\section{REFERENCES}

Balcarczyk J., Prawo do wizerunku i jego komercjalizacja, Warszawa 2009

Barta J., Markiewicz R., Wokót prawa do wizerunku, „Prace z Wynalazczości i Ochrony Własności Intelektualnej” 2002, z. 80 
Craig E. G., The Actor and The Über-Marionette, "A Monthly Journal of the Art of the Theatre" 1909, No 2

Czajkowska-Dąbrowska M., Prawa artystów wykonawców, (w:) J. Barta (red.), System Prawa Prywatnego. Tom 13. Prawo autorskie, Warszawa 2017

Czajkowska-Dąbrowska M., (w:) J. Barta, M. Czajkowska-Dąbrowska, Z. Ćwiąkalski R. Markiewicz, E. Traple, Prawo autorskie i prawa pokrewne. Komentarz, Kraków 2005

Elster A., Genießt die Maske Schutz gegen Wiedergabe der Nachahmung?, „Der neue Weg" 1931, nr 2

Felchner K., Choreografia i pantomima w świetle prawa autorskiego, Warszawa 2012

Flisak D., (w:) D. Flisak (red.), Prawo autorskie i prawa pokrewne. Komentarz, Warszawa 2015

Fronius F. M., Celebrity Impersonators im deutschen und US-amerikanischen Recht, Baden-Baden 2015

Giesen B., Wykonywanie autorskich praw osobistych po śmierci twórcy, „Zeszyty Naukowe Uniwersytetu Jagiellońskiego" 2015, z. 128

Giesen B., O naturze prawa do wizerunku - uwagi na tle rozważań historycznych oraz prawnoporównawczych, (w:) J. Barta, J. Chwalba, R. Markiewicz, P. Wasilewski (red.), Qui Bene Dubitat, Bene Sciet. Księga jubileuszowa dedykowana Profesor Ewie Nowińskiej, Warszawa 2018

Glanc-Walkiewicz A., Gadek B., Image merchandising jako element komercjalizacji dóbr osobistych, „Prawo Mediów Elektronicznych” 2020, z. 1

Götting H.-P., (w:) G. Schricker, U. Loewenheim, Urheberrecht, § 22 KUG, beck-online, 2020

Grzeszak T., Natura prawna maski artystycznej, „Palestra” 2010, nr 11-12

Grzeszak T., Prawo do wizerunku i prawo adresata korespondencji, (w:) J. Barta (red.), System Prawa Prywatnego. Tom 13. Prawo autorskie, Warszawa 2017

Grzeszak T., Reklama a ochrona dóbr osobistych (naruszenie praw osobistych wykorzystanych w reklamie żyjących osób fizycznych), „Przegląd Prawa Handlowego” 2000, nr 2

Grzybowski S., Artysta wykonawca i jego dzieło a zagadnienia ochrony prawnej, „Studia Cywilistyczne" 1968, t. XII

Grzybowski S., Kopff A., Serda J., Zagadnienia prawa autorskiego, Warszawa 1973

Kasprzyk R., Glosa do wyroku SN z dnia 3 października 2007 r., II CSK 207/07, „Palestra” 2009, z. 9-10

Kurosz K., Artystyczne wykonanie utworu. Prawa osobiste i majątkowe aktorów, muzyków i innych wykonawców, Warszawa 2014

Kohler J., Das Eigenbild im Recht, Berlin 1903

Kopff A., Glosa do wyroku SN z 15.04.1965 r., I CR 58/65, „Orzecznictwo Sądów Polskich” 1966, z. 6

Lausen M., Der Schauspieler und sein Replikant, Zeitschrift für Urheber- und Medienrecht 1997, z. 2

Lee Yin Hark, Putting a face to the game: the intellectual property implications of using celebrity likenesses in videogames, GRUR International 2017, No 11

Matlak A., Cywilnoprawna ochrona wizerunku, „Kwartalnik Prawa Prywatnego” 2004, nr 2 
Podolska M., Postać fikcyjna jako przedmiot ochrony prawnoautorskiej, „Biuletyn SAWP" KUL 2018, t. XIII, 15 (2)

Raue P., Eva \& Adel-der Mensch als ,Werk” im Sinne des Urheberechtes, GRUR 2000, z. $11-12$

Rietschel S., Das Recht am eigenen Bilde, „Archiv für die civilistische Praxis” 1903, z. 1-2

Ritterman R., Komentarz do ustawy o prawie autorskim, Kraków 1937

Schneider S., Über die Maske des Schauspielers in den theatertheoretischen Schriften Wsewolod Meyerholds und Bertolt Brechts, München 2009

Sieńczyło-Chlabicz J., Przedmiot, podmiot i charakter prawa do wizerunku, „Przegląd Ustawodawstwa Gospodarczego" 2003, z. 8

Spaemann R., Was macht Personen zu Personen?, (w:) H. Thomas, J. Hattler (Hrsg.), Personen - Zum Miteinander einmaliger Freiheitswesen, Frankfurt am Main 2012

Stagl J. H., Persona: maska z ludzka twarza. O archeologii prawnej prawa osobowego, „Studia Iuridica” 2021, t. LXXXVI

Stanisławska-Kloc S., Ancilliary performers (artistes de complement) i aktualności w sferze artystycznych wykonań, (w:) K. Szczepanowska-Kozłowska, I. Matusiak, Ł. Żelechowski (red.), Opus auctorem laudat. Księga dedykowana Profesor Monice Czajkowskiej-Dąbrowskiej, Warszawa 2019

Voigtländer R., Elster A., Klein H., Die Gesetze, betreffend das Urheberecht an Werken der Literatur und der Tonkunst sowie an Werken der Bilden Kunst und der Photographie, Berlin 1952

Wojnicka E., Prawo do wizerunku w ustawodawstwie polskim, „Zeszyty Naukowe Uniwersytetu Jagiellońskiego" 1990, z. 56

Zoll F., Prawa osobiste $w$ zarysie ze stanowiska prawa prywatnego austriackiego, „Czasopismo Prawno-Ekonomiczne” 1903, R. IV, z. 1-4

Żołnierczuk E., Wokół zagadnień dóbr osobistych artysty wykonawcy, „Zeszyty Naukowe Uniwersytetu Jagiellońskiego. Prace z Prawa Własności Intelektualnej” 2003, nr 83 